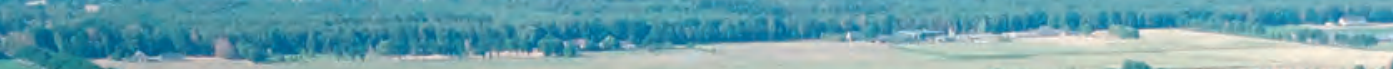

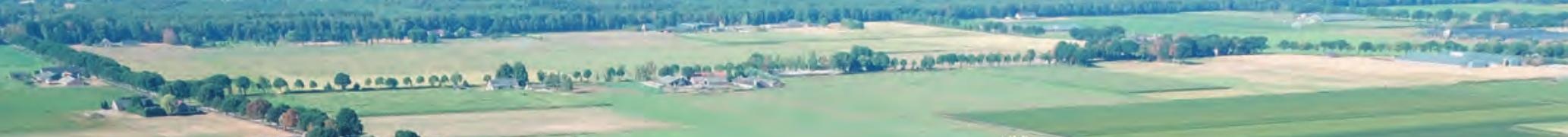

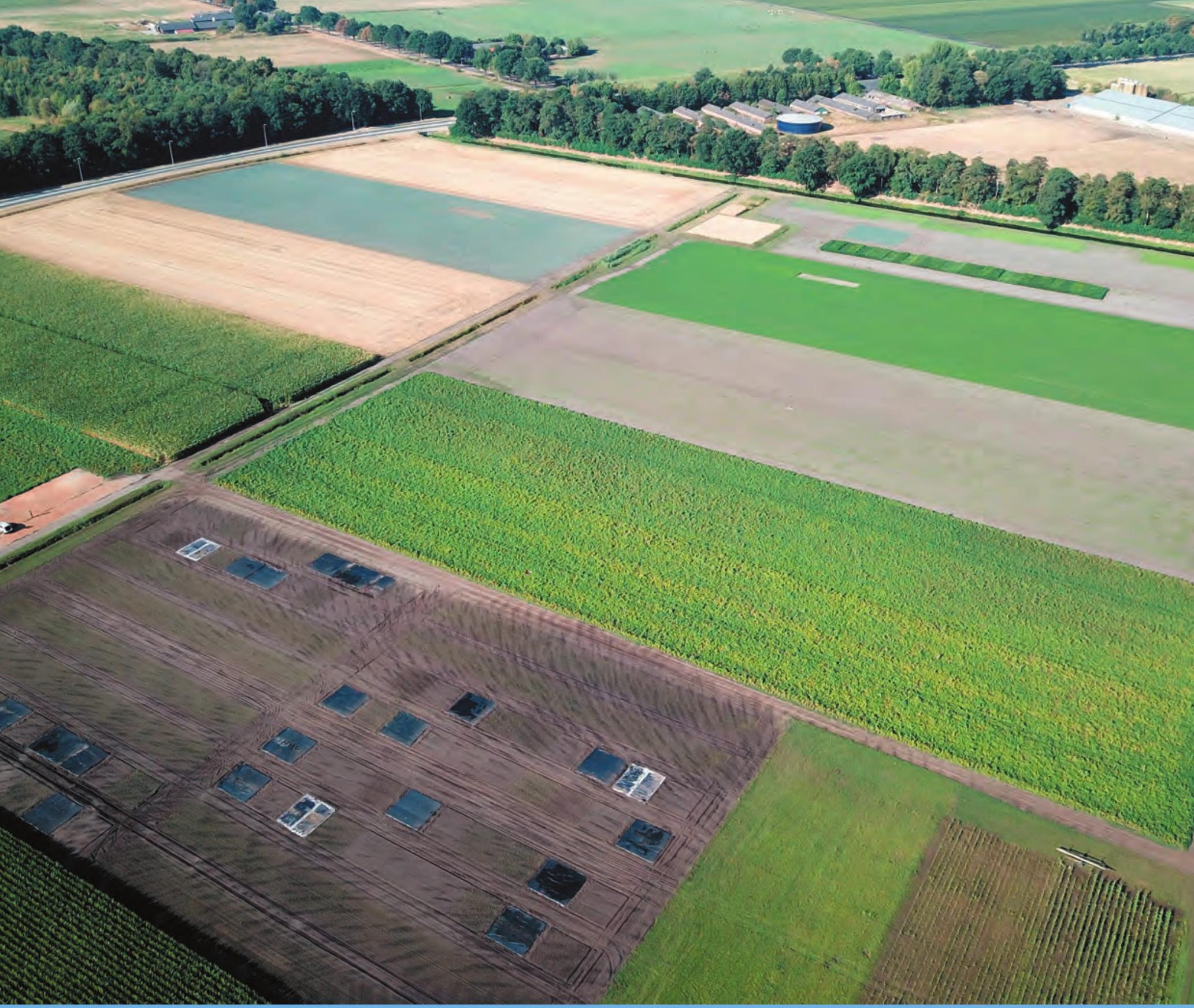

\title{
Indicatoren voor systeemonderzoek in de open teelten en de toepassing daarvan in de systeemproeven van de PPS Beter Bodembeheer
}

Auteurs | Wieke Vervuurt, Isabella Selin-Norén, Marie Wesselink, Harry Verstegen, Derk van Balen, Wiepie Haagsma, Maria-Franca Dekkers, Paulien van Asperen, Marjan Toren en Johnny Visser, Pella Brinkman \& Janjo de Haan | Wageningen University \& Research 


\section{Indicatoren voor systeemonderzoek in de open teelten en de toepassing daarvan in de systeemproeven van de PPS Beter Bodembeheer}

Wieke Vervuurt, Isabella Selin-Norén, Marie Wesselink, Harry Verstegen, Derk van Balen, Wiepie Haagsma, Maria-Franca Dekkers, Paulien van Asperen, Marjan Toren en Johnny Visser, Pella Brinkman \& Janjo de Haan

Dit onderzoek is in opdracht van de Topsector Agri \& Food uitgevoerd door de Stichting Wageningen Research (WR), in het kader van de PPS Beter Bodembeheer (TKI-AF-16064/BO-56-001-005).

WR is een onderdeel van Wageningen University \& Research, samenwerkingsverband tussen Wageningen University en de Stichting Wageningen Research. 
Wieke Vervuurt, Isabella Selin-Norén, Marie Wesselink, Harry Verstegen, Derk van Balen, Wiepie Haagsma, Maria-Franca Dekkers, Paulien van Asperen, Marjan Toren en Johnny Visser, Pella Brinkman \& Janjo de Haan. 2021. Indicatoren systeemonderzoek in de open teelten en de toepassing daarvan in de systeemproeven van de PPS Beter Bodembeheer. Wageningen Research, Rapport WPR-899. 44 blz.

Dit rapport is gratis te downloaden op https://doi.org/10.18174/554803.

(C) 2021 Wageningen, Stichting Wageningen Research, Wageningen Plant Research, Business unit Open Teelten, Postbus 16, 6700 AA Wageningen; T 03174807 00; www.wur.nl/plant-research

KvK: 09098104 te Arnhem

VAT NL no. 8113.83.696.B07

Stichting Wageningen Research. Alle rechten voorbehouden. Niets uit deze uitgave mag worden verveelvoudigd, opgeslagen in een geautomatiseerd gegevensbestand, of openbaar gemaakt, in enige vorm of op enige wijze, hetzij elektronisch, mechanisch, door fotokopieën, opnamen of enige andere manier zonder voorafgaande schriftelijke toestemming van Stichting Wageningen Research.

Stichting Wageningen Research is niet aansprakelijk voor eventuele schadelijke gevolgen die kunnen ontstaan bij gebruik van gegevens uit deze uitgave. 


\section{Inhoud}

Inhoud $\quad 3$

$\begin{array}{lr}\text { Samenvatting } & 5\end{array}$

$\begin{array}{llr}1 & \text { Inleiding } & 7\end{array}$

$\begin{array}{lll}1.1 & \text { Achtergrond } & 7\end{array}$

$\begin{array}{lll}1.2 & \text { Doel } & 7\end{array}$

$\begin{array}{lll}1.3 & \text { Onderscheid met KPI's } & 8\end{array}$

2

$\begin{array}{lr}\text { Methoden } & 9\end{array}$

2.1 Indicatoren $\quad 9$

2.2 Streef- en referentiewaarden 11

$\begin{array}{lll}2.3 & \text { Prestentatie } & 11\end{array}$

$\begin{array}{llr}3 & \text { Indicatorset } & 13\end{array}$

3.1 Indicatoren 13

$\begin{array}{lll}3.2 & \text { Streef- en referentiewaarden } & 18\end{array}$

$\begin{array}{llr}\text { Systeemprestaties } & 24\end{array}$

4.1 Bodemkwaliteit Veenkoloniën 24

4.2 Bodemkwaliteit op zand $\quad 26$

4.3 BASIS $\quad 29$

$5 \quad$ Discussie en conclusie $\quad 31$

5.1 Discussie 31

5.2 Conclusies $\quad 33$

$\begin{array}{lll}5.3 & \text { Aanbevelingen } & 33\end{array}$

Literatuur 34

$\begin{array}{lll}\text { Bijlage } 1 & \text { Presentatie systeemprestaties } & 36\end{array}$

$\begin{array}{llr}\text { Bijlage } 2 & \text { Long-list indicatoren } & 39\end{array}$

$\begin{array}{lll}\text { Bijlage } 3 & \text { Streefwaarden gewasopbrengst } & 41\end{array}$

Bijlage 4 Streefwaarden kwaliteit $\quad 42$

$\begin{array}{lll}\text { Bijlage } 5 & \text { Streefwaarden fosfaatoverschot } & 43\end{array}$ 


\section{Samenvatting}

In het praktijkgerichte systeemonderzoek in de akkerbouw wordt onderzoek gedaan naar de optimalisatie van bedrijfssystemen op verschillende vlakken, met een focus op de bodemkwaliteit. Door de complexiteit van de interacties binnen een agrarisch systeem is een integrale aanpak nodig om deze bedrijfssystemen goed te kunnen evalueren. Door maatschappelijke ontwikkelingen is de reeds bestaande aanpak verouderd. Het doel van dit project is om een indicatorset en systematiek te ontwikkelen om de algemene duurzaamheidsprestatie van een agrarisch bedrijf in kaart te brengen, en deze te toetsen op drie systeemproeven van de PPS Beter Bodembeheer.

Voor het opstellen van de beoogde indicatorset zijn de ecosysteemdiensten als uitgangspunt genomen, en is er een long-list aan indicatoren opgesteld die (aspecten van) deze ecosysteemdiensten belichten. Om tot een integrale selectie te komen, zijn deze indicatoren getoetst aan vier criteria. Ten eerste moet de indicator beïnvloedbaar zijn door management. Ten tweede moet de indicator direct te koppelen zijn aan het gestelde doel. Ten derde moet de indicator direct of indirect meetbaar zijn, en is er voor deze studie gekeken naar indicatoren waar reeds data van beschikbaar was. Tot slot moeten er referentieof streefwaarden beschikbaar zijn, om een prestatie te kunnen interpreteren. Hierin is onderscheid gemaakt op basis van ambitieniveau. Deze procedure heeft geleid tot een selectie van 21 indicatoren, verdeeld over de thema's sociaal-economisch, bodemkwaliteit, emissies en leefomgeving, en circulariteit en grondstoffen.

Een eerste test van deze indicatorset brengt de algemene duurzaamheidsprestaties gedeeltelijk in beeld. Enkele ecosysteemdiensten bleven echter onbelicht. Deze studie laat zien dat er voor enkele ecosysteemdiensten nauwelijks indicatoren zijn afgeleid, met name aan de biodiversiteit, klimaat en sociale aspecten (zoals arbeid en recreatie). Voor deze ecosysteemdiensten moeten er in de toekomst gericht nieuwe indicatoren ontwikkeld en data verzameld worden. Bovendien zijn er niet voor alle indicatoren op elk ambitieniveau streefwaarden bekend. Kortom, de huidige systematiek geeft een eerste indicatie van de duurzaamheidsprestaties van een agrarisch systeem, en dient verder verbeterd te worden om te kunnen gebruiken als beslissingsondersteunend instrument. 


\section{$1 \quad$ Inleiding}

\section{$1.1 \quad$ Achtergrond}

In 2019 heeft WPR in het kader van het KB-project Living Labs en in afstemming met de PPS Beter Bodembeheer en BO-Groen gewerkt aan het ontwikkelen van een indicatorset en systematiek voor het in kaart brengen van de algemene prestatie en duurzaamheidsprestatie van een agrarisch bedrijf. Door de complexiteit van de interacties op een agrarisch bedrijf is een systeem-brede aanpak nodig om de effecten van maatregelen goed te kunnen evalueren. In het praktijkgerichte bedrijfssysteemonderzoek van de WUR Open Teelten werden in het verleden bedrijfssystemen systematisch vergeleken met behulp van verschillende indicatoren, en zijn verschillende sets aan indicatoren ontwikkeld. Door verschillende maatschappelijke ontwikkelingen is deze systematiek niet meer doeltreffend in het huidige format, en mogelijk verouderd. Zo onderzochten Buck et al. (2000) de milieuprestaties van de open teelten, de knelpunten in relatie tot gestelde doelen en perspectiefvolle oplossingsrichtingen. De doelen die zij stelden zijn gebaseerd op wet- en regelgeving zoals de MINAS opgesteld in 1998, waarbij een grenswaarde werd geformuleerd voor 2005 en een streefwaarde voor 2020. Hoewel de streefwaarden verouderd zijn, biedt het rapport een basis om op voort te bouwen. Ook voor het bedrijfssystemenonderzoek werden er gekwantificeerde doelen, randvoorwaarden en gebruikseisen geformuleerd om duurzame bedrijfssystemen te ontwikkelen, evalueren en verbeteren (Wijnands \& Dekking, 2002; Sukkel \& Koot, 2002; Sukkel \& Rovers, 2002; Wijnands \& van Asperen 2002; Wijnands \& Kroonen-Backbier, 2002). Bij het ontwerpen, testen en evalueren van deze bedrijfssystemen werden thema's onderscheiden zoals productkwaliteit, schoon milieu, natuur en landschap, duurzaam gebruik van grondstoffen en bedrijfscontinuïteit, en vervolgens indicatoren, doelen en streefwaarden opgesteld. Deze thema's komen ook terug in de Haan en Garzia-Diaz (2002), waarbij de focus ligt op het ontwikkelen van 'new multi-objective farming systems' voor de vollegrondsgroenteteelt in Europese context. Hoewel de focus van dit rapport ligt op akkerbouwbedrijven in plaats van vollegrondsgroenten, is de methodiek en set aan indicatoren van de Haan en Garzia-Diaz (2002) bruikbaar. Ook in de studie van Tonneijck en de Haan (2006) zijn thema's afgebakend en indicatoren geselecteerd om de duurzaamheidsprestaties van agrarische bedrijven te omschrijven. Het ontwikkelde instrument is complex en omvat 38 indicatoren, waardoor veel gegevens verzameld moeten worden. De studie presenteert een interessant instrument, maar vereenvoudiging is gewenst. Naast sets aan indicatoren op bedrijfssysteem zijn er sets aan indicatoren ontwikkeld met de focus op één thema. Wijnands et al. (2003) ontwikkelen een gestructureerde methodiek voor meer duurzame bedrijfssystemen, met een focus op gewasbescherming in de open teelten. Zij ontwikkelen en testen een gewasbeschermingsplan tegen aanvaardbare kosten en met minimale milieubelasting, waarbij ze een methode ontwikkelen voor het kwantificeren van de milieubelasting door gewasbeschermingsmiddelen in relatie tot streefwaarden. Hierbij wordt het gebruik van gewasbeschermingsmiddelen beoordeeld op integrale wijze, dus in relatie tot een acceptabel economisch resultaat als milieurisico voor lucht, bodem, grondwater, bodemleven en oppervlaktewater. Verschillende indicatoren worden geëvalueerd en er wordt een bruikbare prioritering van deze indicatoren gepresenteerd. Een ander voorbeeld is de indicatorenset 'Bodemkwaliteitsbeoordeling van landbouwgronden in Nederland' (BLN, Hanegraaf et al., 2019 en de Haan et al., 2021), welke ontwikkeld is als meetinstrumentarium om de bodemkwaliteit te karakteriseren en het streefdoel om alle Nederlandse landbouwbodems duurzaam te beheren in 2030 te kunnen monitoren.

\subsection{Doel}

Tezamen geven deze studies richting aan een integrale set aan indicatoren om systeemprestaties te kwantificeren. In dit rapport presenteren we een eerste stap richting vernieuwing van deze systematiek. Deze systematiek zal inzicht moeten geven in de prestaties van bedrijfssystemen, waarmee het ondersteuning biedt bij het onderdeel 'Analyse \& Diagnose' van de prototyperingsmethodiek welke wordt toegepast bij de systeemproeven (de Haan \& Garcia Diaz, 2002). Daarbij levert dit werk een bijdrage aan het evaluatiekader van het Living labs project door te dienen als een evaluatiekader op de schaal van het agrarische bedrijf. 


\subsubsection{Opzet rapport}

Om tot een indicatorenset te komen zijn er verschillende stappen doorlopen. Allereerst is het bedrijfssysteem geconceptualiseerd en is er een methodiek bepaald om indicatoren te typeren. Op basis van de reeds gemeten indicatoren bij de systeemproeven en literatuur is er een longlist aan indicatoren opgesteld. Om tot een selectie aan indicatoren te komen zijn er vier criteria opgesteld om de indicatoren uit de long-list te filteren en een lijst te maken met de meest geschikte indicatoren. Vervolgens zijn er voor deze indicatoren streef- en referentiewaarden geïnventariseerd, en een schaal gedefinieerd om de waarde te presenteren (i.e. normalisatie). Tot slot is deze set aan indicatoren getest aan de hand van data van de systeemproeven Bodemkwaliteit Veenkoloniën (BKV) in Valthermond, Bodemkwaliteit op Zand (BKZ) in Vredepeel en BASIS in Lelystad, hiervoor is (voornamelijk) data van 2019 gebruikt. Bovendien zijn er aanbevelingen geformuleerd om de opzet voor de systeemindicatoren te verbeteren.

\subsection{Onderscheid met KPI's}

Steeds meer nadruk wordt gelegd op het leveren van gewenste (maatschappelijke) diensten zoals schone lucht, schone bodem, schoon water, biodiversiteit, koolstofopslag, regionale eiwitproductie, energie én uiteraard voldoende gezond en veilig voedsel. Er is daarom getracht om voor de nieuwe systematiek indicatoren te selecteren die samen een breed beeld geven van de prestatie van een landbouwbedrijf. Door de verbondenheid van de verschillende processen en componenten van een agrarisch bedrijfssysteem kunnen maatregelen geïmplementeerd in een deel van het bedrijfssysteem effecten hebben op veel verschillende prestatie-indicatoren. Maatregelen gericht op klimaatmitigatie en -adaptatie en het sluiten van kringlopen kunnen daarom op andere systeemaspecten consequenties hebben. Een integraal beeld van de prestaties van het bedrijfssysteem is belangrijk, zodat eventuele neveneffecten van maatregelen zichtbaar worden. Dit doel verschilt van de insteek van de Kritische Prestatie Indicatoren (KPI's). De focus bij KPI's ligt op het handelingsperspectief van de ondernemer en het ontwikkelen van een beloningssystematiek, waarbij gezocht wordt naar indicatoren die minimaal beïnvloed worden door omgevingsfactoren (buiten de boer om): 'KPI's tellen geen grutto's, maar geven wel de omstandigheden die een boer kan beïnvloeden en die een onderbouwde link hebben met het voorkomen van grutto's' (Erisman \& Verhoeven, 2020). In dit project worden zowel input-indicatoren als resultaat-indicatoren opgenomen, welke afhankelijk zijn van de situatie. Kortom, het doel van dit project is het ontwikkelen van een nieuwe set aan indicatoren die een integraal beeld geven van de prestaties van een landbouwbedrijf, waarbij eventuele neveneffecten zichtbaar worden. 


\section{$2 \quad$ Methoden}

\subsection{Indicatoren}

\subsubsection{Invalshoeken}

Voor het selecteren van indicatoren en ontwikkelen van een systematiek kunnen verschillende invalshoeken gebruikt worden. Een agrarisch systeem kan schematisch getekend worden met verschillende inputs en outputs (zie Figuur 2-1). Een deel van de outputs zijn ongewenste neveneffecten. Behalve de inputs en outputs spelen ook andere aspecten van het systeem mee die overkoepelend zijn en iets zeggen over de identiteit van het systeem.

Op basis van deze figuur kan een systeem beoordeeld worden met verschillende 'brillen':

- Productiviteit (zowel agrarische productie als andere ecosysteemdiensten), vooral gericht op de output

- Veerkracht en continuïteit, gericht op het systeem ansich

- Volhoudbaarheid van het systeem

- Capaciteit van het systeem om te herstellen na een verstoring

- $\quad$ Negatieve neveneffecten beperken (verliezen en emissies van nutriënten en gewasbeschermingsmiddelen)

- Efficiëntie - outputs gedeeld door inputs (voor o.a. meststoffen, water, energie, gewasbeschermingsmiddelen, kapitaal en arbeid)

- Gebruik schaarse grondstoffen, inputs (bijv. fosfaatkunstmest en energie)

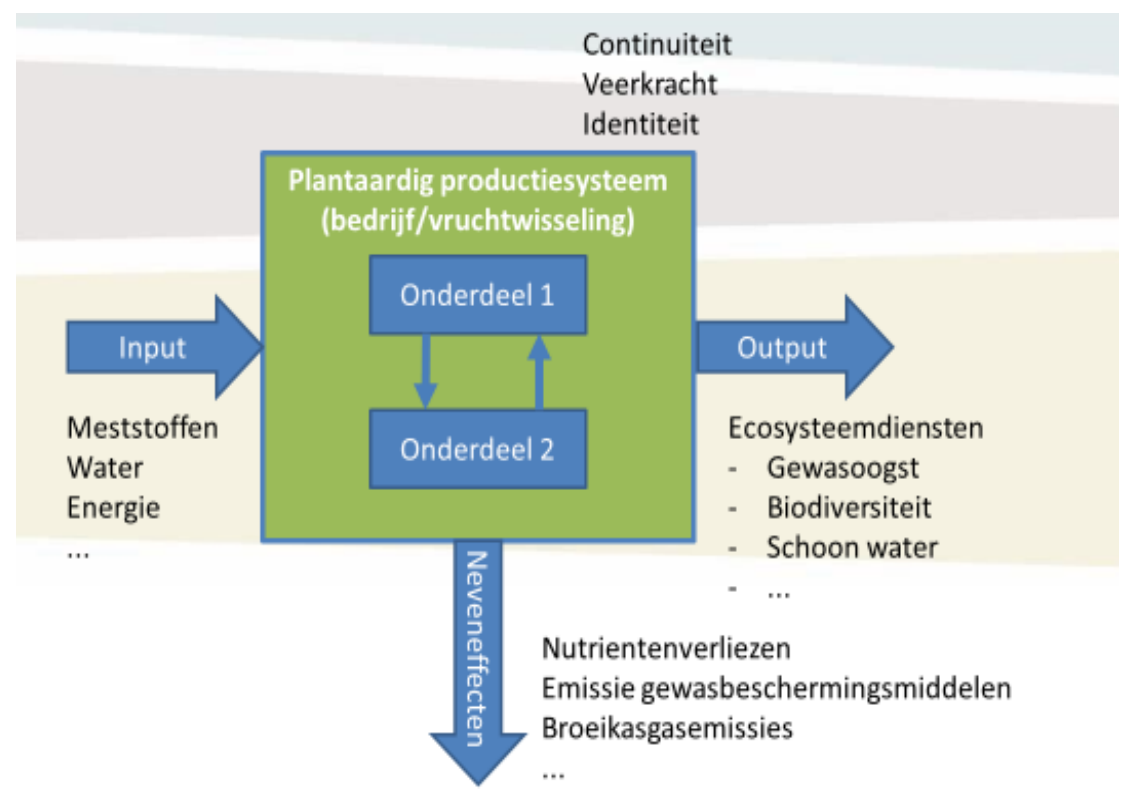

Figuur 2-1 Schematische representatie van bedrijfssysteem. De eigenschappen van het systeem bevinden zich op verschillende locaties in de systeemweergave. Afhankelijk van de bril de gebruikt wordt voor de systematiek, ligt de focus op andere locaties in de systeemweergave.

De diverse brillen kunnen deels overlappen en ook in samenhang gebruikt worden. De keuze voor een specifieke (combinatie van) bril(len) is afhankelijk van het doel van de beoordeling en de achtergrond waar tegen dit gebruikt wordt.

In het voorgaande is gewerkt vanuit het uitgangspunt om een systeem volledig te beoordelen op alle prestaties. Het is echter niet nodig om voor elk doel en situatie alle indicatoren te bepalen. Hiervoor kan een systematiek ontwikkeld worden voor het selecteren van de juiste indicatoren op basis van doel. We hebben voor een eerste uitwerking van de systematiek gekozen om ecosysteemdiensten als "bril" te gebruiken, omdat dit een geschikte tussenstap is tussen doel en indicator, en omdat het een integraal 
beeld kan geven van het systeem. De formulering van ecosysteemdiensten is positief en relatief simpel en dit kan voordelen hebben in het communiceren van resultaten. Daarbij sluit dit goed aan bij de huidige beleidsvragen rond o.a. klimaat, kringlopen en biodiversiteit. De volgende stap is om de geselecteerde indicatoren te koppelen aan ecosysteemdiensten. De indicatoren moeten een indicatie geven voor in hoeverre het systeem ecosysteemdiensten levert. Gebruikmakend van dezelfde conceptsystematiek als uitgewerkt in de BLN, kunnen we werken met systeemfuncties en systeemeigenschappen (Hanegraaf et al., 2019). De systematiek voor bedrijfssystemen komt er dan zo uit te zien als in Figuur 2.

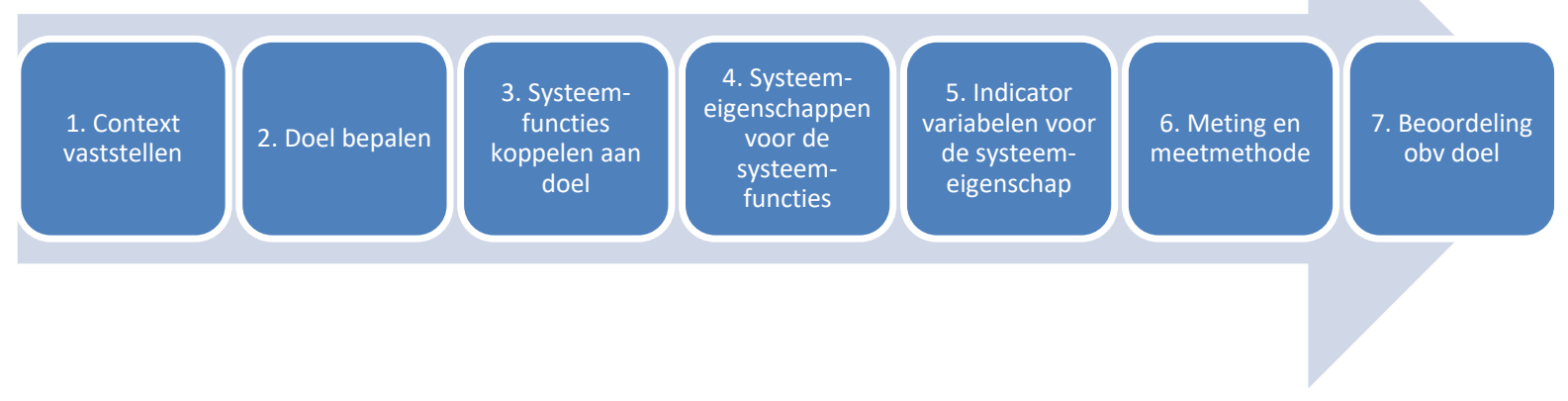

Figuur 2-2 Schematische weergave van de stappen van de systematiek.

Om deze systematiek in te richten worden systeemfuncties bepaald. Systeemfuncties worden hier afgeleid van de klassieke ecosysteemdiensten. De lijst van ecosysteemdiensten verschilt vaak per gebruiker en de lijst die hier gebruikt wordt is ook een aangepaste lijst. Functies worden gedefinieerd door te beantwoorden wat het systeem doet en worden gedefinieerd als algemene capaciteiten van systemen die belangrijk zijn voor landbouw, natuur en maatschappij. De functie 'Productie en benutten van energie' is de enige functie die een uitbreiding is van de originele lijst met ecosysteemdiensten.

De voorlopige lijst met systeemfuncties:

1. Productie van voedsel en/of andere grondstoffen

2. Productie en benutten van energie

3. Bodemvruchtbaarheid, bodemvorming en erosiebeheersing

4. Plaagbeheersing en bestuiving

5. Regulatie van waterkwaliteit

6. Regulatie van waterkwantiteit

7. Regulatie van luchtkwaliteit

8. Regulatie van nutriëntenkringlopen

9. Regulatie van het klimaat

10. Bieden van habitat voor biodiversiteit

11. Bieden van recreatiewaarde en -mogelijkheden

12. Sociale diensten zoals bieden van werk en educatie

De relaties tussen systeemfunctie, systeemeigenschap en indicator worden in de systematiek vastgelegd.

\subsubsection{Criteria}

Naast de integraliteit van de indicatorset zijn er ook eisen die gesteld worden aan de individuele indicatoren. De indicatoren worden geselecteerd door ze te wegen tegen verschillende eisen.

- Veranderbaar door management: De indicator moet beïnvloedbaar zijn door management of management keuzes. Het gaat om het meten van de resultaten van activiteiten en keuzes, en niet het wel of niet uitvoeren van bepaalde maatregelen.

- Doelgericht: De indicator moet relatief makkelijk gekoppeld kunnen worden aan de doelen die men probeert te bereiken. In andere woorden, de indicator moet een goede indicatie geven voor hoe men presteert in relatie tot het behalen van het doel.

- Meetbaar: De indicator moet direct of indirect meetbaar zijn met voldoende nauwkeurigheid en betrouwbaarheid om een uitspraak kunnen maken over de effecten van maatregelen. Die moet ook relatief snel en goedkoop zijn om te bepalen. Bij voorkeur zijn de gegevens al beschikbaar door bedrijfsregistraties of standaard bodem-metingen. 
- Streefwaarden: De indicator moet geschikt zijn voor het formuleren van streefwaarden om zo te kunnen beoordelen in hoeverre een bedrijfssysteem bepaalde doelen bereikt heeft. Deze streefwaarden kunnen gehaald worden uit wet- en regelgeving en zullen vaak systeem-specifiek zijn (grondtype, type agrarisch landgebruik).

Indicatoren kunnen direct voortkomen uit een meting maar ook bepaald worden uit een combinatie van metingen en andere informatie bepaald via een rekenregel.

\subsection{Streef- en referentiewaarden}

Streef- en referentiewaarden ondersteunen de beoordeling van de systeemprestaties en bevorderen de interpretatie van de gemeten of berekende waarde. Het vaststellen van streef- en referentiewaarden is niet eenvoudig, en hangt nauw samen met de gestelde doelen (Hanegraaf et al., 2019; de Buck et al., 2001). Streefwaarden zijn opgesteld om uiteindelijk te voldoen aan het gewenste niveau, en zijn dus doelen (de Buck et al., 2001). Streefwaarden zijn gedefinieerd als de waarde horende bij een beoordeling 'goed' (Hanegraaf et al., 2019). Aan welke waarde 'goed' wordt gekoppeld is afhankelijk van het ambitieniveau. In het project 'Telen met Toekomst' onderscheiden de Buck et al. (2001) drie verschillende manieren om streefwaarden vast te stellen. Als het ware zijn er drie ambitieniveaus te onderscheiden:

- Doelgerichte streefwaarden (ambitieniveau: hoog), waarbij gestreefd wordt naar optimalisatie van het onderliggende thema. Deze waarde kan gebaseerd zijn op wetenschappelijk onderzoek, of voortkomen uit normen uit de wet- en regelgeving.

- Goede landbouwpraktijk (ambitieniveau: middel), waarbij gestreefd wordt naar een optimale bedrijfsvoering. Een achterliggende motivatie van deze streefwaarden is dat zij ambitieus moeten zijn en voor de sector herkenbaar als voorwaarde of resultaat van een goed geslaagde teelt.

- $\quad$ Regionaal gemiddelden (ambitieniveau: laag), waarbij het streven geldt om het beter te doen dan regionaal gangbaar is. Deze waarde kan één getal zijn gebaseerd op een berekend gemiddelde, of een range, door uit te gaan van de spreiding uitgedrukt in de $5 \%$ en $95 \%$ percentielscore (Rutgers et al., 2007). Deze 'streefwaarde' is vergelijkbaar met de referentiewaarden zoals gedefinieerd door Hanegraaf et al. (2019) en de Haan et al. (2021). Indien beschikbaar worden grondsoort-specifieke streefwaarden opgenomen.

\subsection{Prestentatie}

Voor het presenteren van de systeemprestaties zijn verschillende manieren denkbaar. Wijnands en Dekking (2002), Tonneijck en de Haan (2006) en Rutgers et al. (2007) presenteren de systeemprestaties in cirkeldiagrammen (zie Bijlage 1). De buitenkant van de cirkel geeft de streefwaarde aan en in de cirkel wordt de prestatie relatief weergegeven ten opzichte van de streefwaarde. Op deze manier wordt de systeemprestatie helder weergegeven, en is het mogelijk een oordeel te geven op welke indicator goed wordt gepresteerd en welke minder. In deze cirkeldiagrammen wordt telkens één systeem gepresenteerd ten opzichte van één streefwaarde. Om twee of meerdere systemen te kunnen vergelijken en streefwaardes op verschillende niveaus te integreren, wordt een kleine aanpassing voorgesteld (zie Figuur 2-3). De buitenkant van de cirkeldiagram geeft de doelgerichte streefwaarde weer, en verder naar binnen de goede landbouwpraktijk en het regionaal gemiddelde. In plaats van een kleur, zoals is gedaan bij de cirkeldiagrammen in Bijlage 1, worden de systeemprestaties van de systemen met een lijn weergegeven.

Net als bij het cirkeldiagram dienen de indicatoren genormaliseerd te worden. De doelgerichte streefwaarde wordt op $100 \%$ gesteld en de overige streefwaarden en systeemprestaties worden relatief weergegeven ten opzichte van de streefwaarde. Hiervoor wordt dezelfde methodiek gehanteerd als bij Wijnands et al. (2003). In het geval dat er gestreefd wordt naar een hogere waarde (gebruikelijk bij bijvoorbeeld gewasopbrengst), wordt de cirkelwaarde wordt als volgt berekend:

Cirkelwaarde $=1-\frac{\text { doelgerichte streefwaarde-behaalde waarde }}{\text { doelgerichte streefwaarde }}$

Indien de behaalde waarde groter is dan de streefwaarde, wordt de cirkelwaarde vastgesteld op $100 \%$. 
In het geval er wordt gestreefd naar een lagere waarde (gebruikelijk bij bijvoorbeeld het stikstofoverschot), wordt de cirkelwaarde als volgt berekend:

Cirkelwaarde $=1-\frac{\text { behaalde waarde-doelgerichte streefwaarde }}{100}$

Indien de behaalde waarde kleiner is dan de streefwaarde, wordt de cirkelwaarde vastgesteld op 1.

Bij gebrek aan streefwaarden wordt deze op 75 en 50\% gezet respectievelijk voor de landbouwkundige streefwaarde en het regionaal gemiddelde.

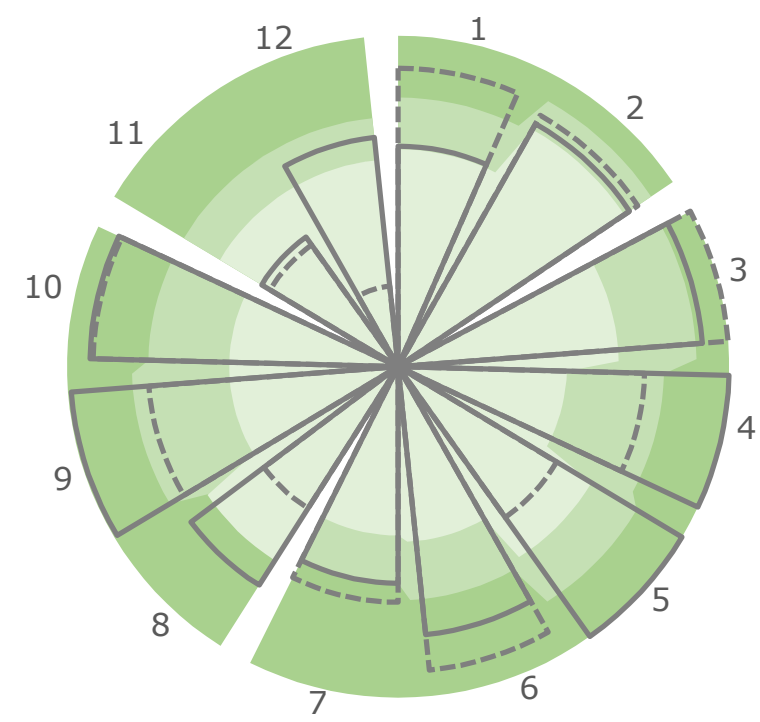

Doelgerichte streefwaarde

Goede landbouwpraktijk

Regionaal gemiddelde

口Systeem A

¿ISysteem B

Figuur 2-3 Voorbeeldweergave van systeemprestaties ten opzichte van elkaar en in vergelijking met verschillende streefwaarden. 


\section{Indicatorset}

De long-list aan indicatoren wordt gepresenteerd in Tabel 51 in Bijlage 1. Aan de hand van de vier criteria is er gekomen tot een set van indicatoren. Enkele indicatoren bleken wel relevant, maar niet toepasbaar op de systeemproeven of teveel overlap te hebben met andere indicatoren, deze zijn later uit de set gehaald. Het gaat om het aandeel natuurelementen (15), de perseelsbreedte (16), koolstofopslag in de bodem (20), het totale energieverbruik (22) en de hoeveelheid opgewekte hernieuwbare energie (23). Hieronder worden de indicatoren van de uiteindelijke set kort toegelicht.

\subsection{Indicatoren}

\subsubsection{Sociaal-economisch}

Hoewel de focus in de afgelopen decennia sterk heeft gelegen op de optimalisatie van de productie en het bedrijfssaldo, moet er binnen dit thema breder gekeken worden. Een duurzaam systeem omvat naast profit en planet ook people, waarbij arbeid niet slechts gezien moet worden als een 'productiemiddel' maar waarbij arbeidsomstandigheden in grote mate het welzijn van de ondernemer bepalen en een indicatie geven van de volhoudbaarheid van het systeem. Indicatoren zoals arbeidsefficiëntie, arbeidsongevallen, arbeidsvreugde, ziekte en verzuim en waarde van het machinepark zijn een goede maat voor arbeidsomstandigheden (Tonneijck \& de Haan, 2006). Hoewel deze indicatoren als erg relevant zijn voor de continuïteit van het systeem en het in beeld brengen van negatieve neveneffecten, sluiten deze indicatoren minder goed aan bij de functies van de ecosysteemdiensten. Bovendien bleken deze indicatoren, in tegenstelling tot op bedrijfsniveau, niet toepasbaar binnen het systeemonderzoek. De indicatoren opbrengst, kwaliteit van het product en saldo sluiten beter aan bij de ecosysteemdiensten en voldoen aan de gestelde criteria, waardoor de selectie beperkt blijft tot deze drie indicatoren (zie Tabel 3-1).

Tabel 3-1 Sociaal-economische indicatoren

\begin{tabular}{lll}
\hline $\mathrm{Nr}$. & Indicator & Eenheid \\
\hline 1 & Opbrengst & ton ha ${ }^{-1}$ \\
2 & Kwaliteit van het product & - \\
3 & Saldo & $€$ \\
\hline
\end{tabular}

\section{Opbrengst}

De gewasopbrengst is een maat voor de productiviteit. Tevens reflecteert de gewasopbrengst de bedrijfsvoering, bemestingsstrategie, de bodemkwaliteit en de ziekte- en plaagbeheersing. In dit rapport wordt de opbrengst uitgedrukt in marktbare opbrengst in ton ha-1.

\section{Kwaliteit}

De kwaliteit van het product is uit te drukken op verschillende manieren. De Haan en Garzia-Diaz (2002) drukken de kwaliteit uit in het percentage producten dat in kwaliteitsklasse I valt. Tonneijck en de Haan (2006) voegen daar de nitraatconcentratie van het product aan toe, omdat hoge gehalten nitriet schadelijk zijn voor de mens. Volgens de methodiek van het bedrijfssystemenonderzoek wordt uitgegaan van de kenmerken die door de afnemer worden bepaald, en zijn gewasspecifiek (Wijnands \& Dekking, 2002). In de rapportages van de systeemproeven wordt ook per gewas een kwaliteitseigenschap gerapporteerd, hoe de kwaliteit van het product wordt uitgedrukt is afhankelijk van het geteelde gewas (de Haan et al., 2017; de Haan et al., 2020). Wegens databeschikbaarheid wordt deze methodiek overgenomen. De kwaliteitseisen per gewas zijn opgenomen in Tabel 3-2. 
Tabel 3-2 Indicatoren kwaliteit van het product

\begin{tabular}{lll}
\hline Gewas & Kwaliteitsindicator & Eenheid \\
\hline Consumptieaardappel & OWG & Gram \\
Erwt & TM & Index \\
Grasklaver & Droge stof & $\%$ \\
Kool & Bladaantasting & $\%$ \\
Lelie & Aantal bollen & $\# /$ ha \\
Peen & Tarra & $\%$ \\
Pootaardappel & Schurft & $\%$ \\
Prei & Tarra & $\%$ \\
Snijmais & VEM & - \\
Suikerbiet & Suikergehalte & $\%$ \\
Ui & Tarra & $\%$ \\
Zetmeelaardappel & Zetmeelgehalte & $\%$ \\
Zomergerst & Eiwitgehalte & $\%$ \\
Zomertarwe & Vochtgehalte & $\%$ \\
\hline
\end{tabular}

\section{Saldo}

Deze indicator is van belang omdat deze het duurzaamheidsaspect profit vertegenwoordigt, en mogelijke trade-offs inzichtelijk maakt. Deze indicator is echter ingewikkeld om te berekenen voor systeemproeven op semi-praktijkschaal, en wordt voorlopig buiten beschouwing gelaten.

\subsubsection{Bodemkwaliteit}

Voor het beoordelen van de bodemkwaliteit zijn verschillende sets aan indicatoren opgesteld, zoals de Minimale Data Set, de bodemconditiescore en Soil Health Index (de Haan et al., 2019; Molendijk et al., 2018). Een lijst met de meest relevante indicatoren om de bodemkwaliteit van landbouwbodems breed vast te stellen is samengesteld in de BLN (Hanegraaf et al., 2019 en de Haan et al., 2021). De eisen waaraan de indicatoren in de BLN zijn getoetst overlappen met de eisen van deze studie, en daarom is er voor de karakterisering van de bodemkwaliteit de BLN als uitgangspunt genomen. Uit deze set is gekozen voor stikstof, fosfaat, kali, aanvoer van effectieve organische stof (EOS), hot water carbon (HWC), indringingsweerstand, bulkdichtheid en potentieel mineraliseerbare stikstof (PMN), zie Tabel 3-3. Zoals aangegeven in 2.1.1 kan er op verschillende manieren gekeken worden naar de belangrijkste nutriënten, namelijk input, output, efficiëntie of negatieve neveneffecten (zie Figuur 2-1). In de BLN is de status van deze nutriënten opgenomen, welke een indicatie geven van de systeemeigenschappen. Hoewel de focus in de BLN ligt op het karakteriseren van de bodemeigenschappen (zie ook Figuur 1 in Hanegraaf et al., 2019), en de focus van deze studie ligt op de bodemfuncties worden de stikstof- en fosfaatstatus toch opgenomen als indicator voor de nutriëntenvoorziening, omdat er in de literatuur veel bekend is over de relatie tussen de bodemvoorraad en gewasvoorziening en wegens de beschikbaarheid van streefwaarden. Aanvullend zijn het stikstof- en fosfaatoverschot meegenomen als maat voor mogelijke nutriëntenverliezen. Het gewenste stikstof- en fosfaatoverschot hangt sterk af van de stikstofen fosfaatstatus. De wens is om de streefwaarde voor het stikstof- en fosfaatoverschot afhankelijk te maken van de stikstof- en fosfaatstatus, waardoor de laatstgenoemden kunnen komen te vervallen (zie 2.2).

Tabel 3-3 Indicatoren bodemkwaliteit

\begin{tabular}{lll}
\hline $\mathrm{Nr}$. & Indicator & Eenheid \\
\hline 4 & Stikstofoverschot & $\mathrm{kg} \mathrm{N} / \mathrm{ha}$ \\
5 & Fosfaatoverschot & $\mathrm{kg} \mathrm{P} 2 \mathrm{O} 5 / \mathrm{ha}$ \\
6 & Stikstofstofstatus & $\mathrm{mg} / \mathrm{kg}$ \\
7 & Fosfaatstatus (pw-getal) & $\mathrm{mg} \mathrm{P} 205 / \mathrm{liter}$ \\
8 & Kalistatus & \\
9 & EOS aanvoer & $\mathrm{kg} \mathrm{EOS} / \mathrm{ha}$ \\
10 & Bodem organische stof & $\%$ \\
11 & HWC & $\mathrm{mg} / \mathrm{kg}$ \\
12 & Indringingsweerstand & $\mathrm{Mpa}$ \\
13 & bulkdichtheid & $\mathrm{kg} / \mathrm{m} 3$ \\
14 & PMN & $\mathrm{kg} \mathrm{N} / \mathrm{ha}$ \\
\hline
\end{tabular}




\section{Stikstofoverschot}

Het stikstofoverschot is een maat voor de hoeveelheid stikstof die na de teelt achterblijft in de bodem en gevoelig is voor uitspoeling uit de wortelzone. Het stikstofoverschot wordt berekend volgens de methode zoals het RIVM gebruikt voor het Landelijk Meetnet effecten Mestbeleid (Lukács et al., 2019). Deze methode gaat uit van een evenwichtssituatie, er wordt verondersteld dat op de lange termijn de aanvoer van organische stikstof in de vorm van gewasresten en organische mest gelijk is aan de jaarlijkse afbraak. Een uitzondering wordt gemaakt voor veen- en dalgronden, waarvoor een standaard hoeveelheid gemineraliseerde stikstof wordt genomen (Lukács et al., 2019). De aanvoer van nietwerkzame stikstof uit organische mest zou hierbij geen problemen moeten opleveren, ook met een volledig organische bemesting is de streefwaarde voor het stikstofoverschot haalbaar, al leidt het toepassen van organische mest onvermijdelijk tot een hoger stikstofoverschot (Wijnands \& Dekking, 2002).

\section{Fosfaatoverschot}

Het fosfaatoverschot is een indicator voor verliezen. Echter fosfaatprocessen in de bodem zijn complex, een hoge aanvoer van fosfaat hoeft niet te leiden tot uitspoeling, maar is afhankelijk van de fosfaatverzadiging in de bodem. Desalniettemin is het fosfaatoverschot een bruikbare indicator om te sturen op bedrijfsverbetering, met name wanneer de streefwaarde gedefinieerd wordt afhankelijk van de fosfaattoestand. Het fosfaatoverschot wordt berekend op dezelfde wijze als het stikstofoverschot, al wordt depositie en binding door vlinderbloemigen vanzelfsprekend buiten beschouwing gelaten.

\section{Stikstofstatus}

De stikstofstatus heeft betrekking op de reserve in de bodem en is een maat voor de bodemvruchtbaarheid. De stikstofstatus wordt uitgedrukt in $\mathrm{kg} \mathrm{N} \mathrm{ha}^{-1}$ en in $\mathrm{mg} \mathrm{N} \mathrm{ha}^{-1}$, wegens de beschikbaarheid van streefwaarden is gekozen om $\mathrm{N}$-totaal op te nemen als $\mathrm{mg} \mathrm{kg}^{-1}$.

\section{Fosfaatstatus}

De fosfaatstatus is een relevante indicator voor de bodemvruchtbaarheid en bepaalt in grote mate de gewasopbrengst van een aantal gewassen in de vruchtwisseling. Fosfaat in de bodem kan op verschillende manieren gemeten en uitgedrukt worden, zoals $\mathrm{P}$-Al (bodem gebonden reserves), $\mathrm{P}-\mathrm{CaCl} 2$ (bodemoplossing) en het Pw-getal (combinatie van direct beschikbaar en nalevering van fosfaat). Het Pw-getal per 1 januari 2022 in de fosfaatwetgeving vervangen zal worden door P-Al, de nieuwe indeling sluit nauwkeuriger aan bij de fosfaattoestand van een perceel en de gewenste fosfaatbemesting. Omdat tot nu toe $\mathrm{Pw}$ is gebruikt als indicator in de uitvoering van de proeven wordt voor dit rapport het $\mathrm{Pw}$ getal aangehouden.

\section{Kalistatus}

De kalistatus is een relevante indicator voor de bodemvruchtbaarheid, uit veeljarige proefvelden is namelijk gevonden dat op klei en löss de kalitoestand van de grond invloed heeft op de opbrengst en de kwaliteit van met name aardappelen (HBB, n.d.). Om te voorkomen dat de beschikbaarheid van kali geheel afhankelijk is van de bemesting, wordt er gestreefd naar een bepaalde kalistatus, uitgedrukt in het K-getal.

\section{EOS aanvoer}

Effectieve organische stof (EOS) is het deel van de aangevoerde organische stof uit gewasresten, organische mest en groenbemesters dat één jaar na toediening overblijft in de bodem. De aanvoer van EOS is daarom een maat voor het gedeelte organische stof dat onderdeel wordt van de bodem, deze moet voldoende hoog blijven om het bodem organische stofgehalte op peil te houden.

\section{Bodem organische stof}

Organische stof heeft een positieve invloed op belangrijke aspecten van de bodemvruchtbaarheid, zo dient het als voeding voor het bodemleven, levering van nutriënten voor de gewasgroei, draagt het bij aan een betere bodemstructuur en waterregulering en de uitwisseling van kationen.

\section{HWC}

Met de HWC-methode wordt met name de labiele koolstoffractie in de bodem gemeten, welke sterk gerelateerd blijkt aan de microbiële biomassa (Ghani, 2003). Laatstgenoemde wordt vervolgens in verband gebracht met bodemweerbaarheid tegen bodemziekten. Bovendien is de HWC gevoelig voor bodemmanagement, zoals de intensiteit van de bodembewerkingen en bemesting. De HWC blijkt daarmee een goede indicator te zijn voor de algehele bodemkwaliteit (Ghani, 2003). 


\section{Indringingsweerstand}

Bodemverdichting is niet opgenomen in de indicatorenset van Tonneijck en de Haan (2006), Wijnands en Dekking (2002) en de Buck et al. (2000), bodemstructuur speelt nauwelijks een rol in deze sets. In de noodzakelijke indicatoren om de bodemgezondheid te kunnen beoordelen is de bodemstructuur wel een thema, en ook onderdeel van de BLN. Bodemstructuur is een belangrijk aspect van de bodemvruchtbaarheid, omdat het een rol speelt bij de wortelgroei en de vocht- en nutriëntenvoorziening. Met de indringingsweerstand wordt de mate van drukweerstand van de bodem uitgedrukt, de indringingsweerstand is daarmee een maat voor bodemverdichting (de Haan et al., 2019). Bovendien heeft van den Elsen et al. (2020) de indringingsweerstand aangemerkt als noodzakelijke indicator voor het beoordelen van de bodemgezondheid.

\section{Bulkdichtheid}

Een andere veelgebruikte indicator voor de bodemstructuur is de droge bulkdichtheid. De droge bulkdichtheid wordt uitgedrukt in gewicht per volume, en is een indicatie voor het aandeel poriën in de bodem. Het aandeel poriën is van belang voor lucht, vocht, transport van nutriënten en de wortelgroei. De droge bulkdichtheid geeft daarmee enerzijds inzicht in bodemverdichting en anderzijds in de draagkracht van de bodem. Echter, de droge bulkdichtheid is ook afhankelijk van textuur en organisch stofgehalte, hier dient rekening mee gehouden te worden bij het vaststellen van streefwaarden.

\section{PMN}

De PMN geeft een indicatie van de actieve bacteriën en schimmels. De PMN geeft geen informatie over de diversiteit van het bodemleven en de totale microbiële massa, al vertoont PMN goede correlaties met de totale microbiële biomassa.

\subsubsection{Emissies en leefomgeving}

De indicatoren binnen het onderdeel 'emissies en leefomgeving' zijn gericht op het beperken van de negatieve neveneffecten van het productiesysteem. Gekozen is voor het aandeel bodembedekking, het gebruik van gewasbeschermingsmiddelen en de minerale stikstof in het najaar. In de long-list zijn enkele indicatoren opgenomen met betrekking tot biodiversiteit, zoals de vogelindex, gemiddelde perceelsbreedte en aantal natuurelementen. Er is gekozen om deze indicatoren niet op te nemen in de huidige set aan systeemindicatoren. In tegenstelling tot het bedrijfsniveau, zijn deze indicatoren niet toepasbaar in de systeemproeven. Ter illustratie, in het bedrijfssysteemonderzoek worden de systemen geward aangelegd op één of meerdere percelen, waardoor het niet mogelijk is om een natuurelement toe te schrijven aan een afzonderlijk systeem.

Tabel 3-4 Indicatoren emissies en leefomgeving.

\begin{tabular}{lll}
\hline $\mathrm{Nr}$. & Indicator & Eenheid \\
\hline 17 & Bodembedekking & Percentage \\
18 & Gebruik gewasbeschermingsmiddelen & $\mathrm{kg} \mathrm{actieve} \mathrm{stof} \mathrm{ha}{ }^{-1}$ \\
19 & N-min najaar & $\mathrm{kg} \mathrm{N} \mathrm{ha}^{-1}(0-90 \mathrm{~cm})$ \\
\hline
\end{tabular}

\section{Bodembedekking}

In een voorgaande set aan indicatoren werd slechts gekeken naar het percentage bedekking in de winter, met het oog op wind- en watererosie (Tonneijck en de Haan, 2006). De meest erosiegevoelige periode is echter tussen mei en september (Reubens et al., 2012). Omdat bodembedekking daarnaast dient als voeding voor het bodemleven, structuur geeft aan de bodem en het risico op uitspoeling beperkt, wordt de bodembedekking over het gehele jaar bekeken (Koopmans et al., 2017). Een potentiële indicator voor erosiegevoeligheid is de bedekkingsgraad, met behulp van een dimensieloze parameter die varieert tussen 0 (volledige bedekking) en 1 (onbedekte bodem) (Reubens et al., 2012). Deze parameters, als ook de opkomst en afsterving van het gewas, zijn niet voor elke systeemproef bijgehouden. Daarom is er gekozen voor de periode tussen zaaien/poten en oogsten/onderwerken ten opzichte van een heel kalenderjaar.

\section{Gebruik gewasbeschermingsmiddelen}

Er bestaan een aantal indicatoren die het schadelijke effect van gewasbeschermingsmiddelen kwantificeren, hierbij kan onderscheid gemaakt worden naar het effect op de milieucompartimenten (bodem, water en lucht) en levende organismen (Wijnands \& Dekking, 2002). Een indicator die de per middel, gewas, perceel of bedrijf op de concentratie in het grondwater, bodem en lucht berekend is de Blootstellings-Risico Index (BRI). Een andere veelgebruikte indicator is de MilieuBelastingsPunten, welke per toepassing wordt berekend en op bedrijfsniveau een indicatie geeft van het aantal jaarlijkse 
overschrijdingen van de grenswaarde. Momenteel is een nieuwe indicator in ontwikkeling, de 'Milieuindicator Gewasbescherming'. Voorlopig is gekozen voor het gebruik van gewasbeschermingsmiddelen uitgedrukt in kilogram actieve stof per hectare. Deze indicator is echter niet één-op-één gerelateerd aan de actuele ziekte- en plaagdruk en geeft geen inzicht in het gebruik van de meest belastende middelen.

\section{$\mathbf{N}$-min najaar}

$\mathrm{N}$-min najaar wordt gebruikt als maat voor stikstof uitspoeling. Het meten van de $\mathrm{Nmin}$ in de bodem (in de bovenste $90 \mathrm{~cm}$ ) is een relatief eenvoudige methode en geeft een indicatie van de nitraatconcentratie in het grondwater (Hoving, 2005). Echter, uit een analyse van Noij et al. (2019) blijkt deze relatie tussen het nitraatresidu in het najaar in de laag $0-90 \mathrm{~cm}$ en de gemeten nitraatconcentratie in het bovenste grondwater niet eenvoudig te bepalen is, omdat de betrouwbaarheid van de puntmetingen van de nitraatconcentratie van het bovenste grondwater op perceelsniveau beperkt is. Door het grote aantal meetpunten is een meting op regioniveau wel betrouwbaar. Er blijkt geen duidelijke relatie tussen het nitraatresidu in de laag $0-90 \mathrm{~cm}$ en de nitraatconcentraties in het grondwater. In combinatie met andere factoren (zoals bodem, grondwaterstand en gewas) wordt wel een significant verband gevonden met de nitraatconcentratie in het grondwater $\left(r^{2}=0,55\right)$. Noij et al. (2019) concluderen dat voor het risico op uitspoeling gekoppeld aan het management een combinatie aan indicatoren gewenst is, zoals het stikstofbodemoverschot, nitraatresidu, vanggewas en de dynamiek van organische N. Met uitzondering van de laatstgenoemde zijn deze parameters opgenomen in de set. Bovendien geeft $\mathrm{N}$-min najaar (0$90 \mathrm{~cm}$ ) een indicatie van onbenut potentieel, en wordt daarom voorlopig opgenomen in de set aan indicatoren.

\subsubsection{Circulariteit en grondstoffen}

De indicatoren binnen 'circulariteit en grondstoffen' zijn met name gericht op het minimaliseren van de negatieve neveneffecten, door het beperken van het gebruik van niet-hernieuwbare grondstoffen (zoals diesel en kunstmest), het efficiënt inzetten van natuurlijke hulpbronnen (zoals zoet water) en het sluiten van kringlopen (zoals het gebruik van organische mest). Het direct meten van deze negatieve neveneffecten, bijvoorbeeld in termen van broeikasgassen, is ingewikkeld en daarom zijn de inputs opgenomen als indicator, zie Tabel 3-5.

Tabel 3-5 Indicatoren circulariteit en grondstoffen

\begin{tabular}{lll}
\hline $\mathrm{Nr}$. & Indicator & Eenheid \\
\hline 21 & Beregening & $\mathrm{mm} /$ ton \\
24 & Diesel & - \\
25 & Aandeel organische N & $\%$ \\
26 & Aandeel organische P2O5 & $\%$ \\
\hline
\end{tabular}

\section{Waterverbruik}

Een optimale vochtvoorziening is essentieel voor een optimale opbrengst, en daarnaast van belang bij een efficiënte benutting van nutriënten. Beregening dient ingezet te worden ter ondersteuning van een efficiënt gebruik van overige productiemiddelen, wat zich uit in een hogere opbrengst (Buck et al., 2000). Voor het efficiënt gebruik van water is de beregening in $\mathrm{mm}$ per ton opbrengst een maat.

\section{Dieselverbruik}

Deze indicator is van belang in het licht van meerdere ecosysteemdiensten, zoals energie, luchtkwaliteit en klimaat. Deze indicator is echter ingewikkeld om te berekenen voor de proefbedrijven, wordt voorlopig buiten beschouwing gelaten.

\section{Aandeel organische stikstof in de bemesting}

Met het oog op kringlooplandbouw wordt bij het bodembeheer toegewerkt naar het toepassen van (bewerkte) organische mest en steeds minder kunstmest. Het aandeel stikstof uit niet-kunstmest is daarvoor een maat, waarbij de totale $\mathrm{N}$ uit organische mest en stikstofbinding gedeeld wordt op de totale $\mathrm{N}$ aanvoer. Stikstofdepositie en de aanvoer via plant-, poot- en zaaimateriaal worden buiten beschouwing gelaten om een vergelijking met data op landelijk niveau te vereenvoudigen.

\section{Aandeel organisch fosfaat in de bemesting}

Met het oog op kringlooplandbouw wordt bij het bodembeheer toegewerkt naar het toepassen van (bewerkte) organische mest en steeds minder kunstmest. Het aandeel fosfaat uit niet-kunstmest is daarvoor een maat, waarbij de totale P2O5 uit organische mest gedeeld wordt op de totale P2O5 aanvoer. 


\subsection{Streef- en referentiewaarden}

Een overzicht van de gevonden streefwaarden op de drie niveaus worden gepresenteerd in Tabel 2-6. Streefwaarden overgenomen uit wetenschappelijke literatuur zijn weergegeven in groen, referentiewaarden overgenomen uit wetenschappelijke literatuur zijn weergegeven in geel, en waarden afgeleid uit databases gebaseerd op Eurofins analyse-uitslagen of uit eigen inschatting in oranje. Geen gegevens in lichtgrijs. 
Tabel 3-6 De streefwaarden voor de systeemindicatoren, uitgesplitst naar ambitieniveau en grondsoort.

\begin{tabular}{|c|c|c|c|c|c|c|c|c|c|c|c|}
\hline \multirow[b]{3}{*}{$\mathrm{Nr}$} & \multirow[b]{3}{*}{ Naam } & \multirow[b]{3}{*}{ Eenheid } & \multicolumn{3}{|c|}{ Ambitieniveau: hoog } & \multicolumn{3}{|c|}{ Ambitieniveau: middel } & \multicolumn{3}{|l|}{ Ambitieniveau: laag } \\
\hline & & & \multicolumn{3}{|c|}{ Doelgerichte streefwaarde } & \multicolumn{3}{|c|}{ Beste landbouwpraktijk } & \multicolumn{3}{|l|}{ Regionaal gemiddelde } \\
\hline & & & Klei & Zand & Dal & Klei & Zand & Dal & Klei & Zand & Dal \\
\hline 1 & Opbrengst* & & & & & & & & & & \\
\hline 2 & Kwaliteit** & & & & & & & & & & \\
\hline 4 & $\mathrm{~N}$-overschot & $\mathrm{kg} \mathrm{N} / \mathrm{ha}$ & $60^{k}$ & $60^{k}$ & $60^{k}$ & $90^{\mathrm{a}}$ & $70^{\mathrm{a}}$ & $70^{\mathrm{a}}$ & $117^{\mathrm{b}}$ & $94^{\mathrm{b}}$ & $94^{b}$ \\
\hline 5 & P2O5-overschot*** & & & & & & & & $13^{\mathrm{c}}$ & $10^{c}$ & $10^{\circ}$ \\
\hline 6 & $\mathrm{~N}$-status & $\mathrm{mg} / \mathrm{kg}$ & & & & & & & $1459-1942^{d}$ & $1243-1841^{d}$ & $1324-4408^{\mathrm{C}}$ \\
\hline 7 & Pw-getal & $\mathrm{mg} \mathrm{P2O5/l}$ & & & & $25^{\mathrm{e}}$ & $30^{\mathrm{e}}$ & $30^{\mathrm{e}}$ & $70^{\mathrm{f}}$ & $78^{\mathrm{f}}$ & 78 \\
\hline 8 & Kali-getal & & & & & $18^{\mathrm{e}}$ & $11^{\mathrm{e}}$ & $11^{\mathrm{e}}$ & & & \\
\hline 9 & OS aanvoer & $\mathrm{kg} \mathrm{EOS/ha}$ & \multicolumn{3}{|c|}{$\geq$ afbraak } & 2000 & 2000 & 2000 & $1910^{g}$ & $2240^{9}$ & $1980^{\circ}$ \\
\hline 10 & OS gehalte & $\%$ & $>2,76-3,62^{\mathrm{h}}$ & $>1,90-3,28^{\mathrm{h}}$ & & \multicolumn{3}{|c|}{$1,5+0,1 *$ lutum $\%{ }^{i}$} & $2,8-3,7^{\mathrm{d}}$ & $3,5-5,3^{d}$ & $4,5-15,8^{\mathrm{c}}$ \\
\hline 11 & HWC & $\mathrm{mg} / \mathrm{kg}$ & & & & & & & $500^{j}$ & $500-2000^{j}$ & $500-2000$ \\
\hline 12 & Indringingsw. & Mpa & 0 & 0 & 0 & $<3^{\prime}$ & $<3^{\prime}$ & $<3^{\prime}$ & $0,61-1,56^{d}$ & & \\
\hline 13 & Bulkdichtheid & $\mathrm{g} / \mathrm{cm} 3$ & & & & $1,15-1,41^{\prime}$ & $1,2-1,51^{1}$ & $1,2-1,51^{\prime}$ & $1,15-1,43^{d}$ & $1,14-1,64^{d}$ & $0,53-1,75^{c}$ \\
\hline 14 & PMN & $\mathrm{mg} / \mathrm{kg}$ & & & & $60-80^{d}$ & $60-80^{d}$ & $60-80^{d}$ & & & \\
\hline 17 & Bodembedekking & $\%$ & 100 & 100 & 100 & & & & & & \\
\hline 18 & Gewasbescherming & & 0 & 0 & 0 & $6,5^{k}$ & $6,5^{k}$ & $6,5^{k}$ & & & $* * * *$ \\
\hline 19 & $\mathrm{~N}$-min najaar & & & & & $79,2^{1}$ & $39,6^{1}$ & & & & \\
\hline 21 & Beregening & $\mathrm{mm} /$ ton prod & 0 & 0 & 0 & & & & & & \\
\hline 25 & Organisch-N & $\%$ & 100 & 100 & 100 & & & & $46^{\mathrm{m}}$ & $62^{m}$ & $62^{m}$ \\
\hline 26 & Organisch-P2O5 & $\%$ & 100 & 100 & 100 & & & & $84^{n}$ & $94^{n}$ & $94^{n}$ \\
\hline
\end{tabular}

* Per gewas bepaald, zie 41Bijlage 3

** Per gewas bepaald, zie Bijlage 4

*** Voor de beste landbouwpraktijk bepaald per fosfaatklasse, zie Bijlage 5

$* * * *$ Per bouwplan bepaald, zie 3.2.3. 


\subsubsection{Sociaal-economisch}

\section{Opbrengst}

De streefwaarden zijn per gewas bepaald, zie Tabel 5-2 in Bijlage 3. De doelgerichte streefwaarde is de potentiële productie, dus het biofysische maximum. Deze getallen komen uit de literatuur. Wanneer niet beschikbaar is de hoogst behaalde opbrengst behaald op het proefbedrijf gebruikt. De streefwaarde voor de beste landbouwpraktijk is gelijkgesteld aan de top $20 \%$ van de beste praktijkopbrengsten in de regio. Deze getallen zijn over het algemeen bij de systeemproefhouders bekend. Het regionaal gemiddelde is het laagste ambitieniveau en gebaseerd op de getallen van Agrimatie, omdat deze specifiek per jaar bekend zijn. Indien niet opgenomen in Agrimatie zijn de cijfers uit de KWIN gebruikt. De cijfers in de KWIN zijn gebaseerd op een praktijkgemiddelde, waarbij uitgegaan wordt van een geslaagde teelt.

\section{Kwaliteit}

De streefwaarden voor de kwaliteit van het product is per gewas bepaald, en worden samengevat in bijlage 4 . Voor de doelgerichte streefwaarden wordt een zo hoog mogelijke kwaliteit nagestreefd, deze waarden zijn afgeleid uit de literatuur, komen uit jaarverslagen van afnemers, of zijn gebaseerd op de hoogste kwaliteitsprestaties in de data van het proefbedrijf. De streefwaarden voor de goede landbouwpraktijk is gebaseerd op de kwaliteitseisen zoals vastgesteld door de afnemer, of op de beste $20 \%$ uit de regio. De regionaal gemiddelden zijn afgeleid uit de literatuur, komen uit jaarverslagen van de afnemers, of zijn gebaseerd op data van het proefbedrijf.

\section{Saldo}

Geen streefwaarde vastgesteld op dit moment.

\subsubsection{Bodemkwaliteit en gewas}

Streef- en referentiewaarden zijn zoveel mogelijk gebruikt uit de BLN (Hanegraaf et al., 2019; de Haan et al., 2021), Rutgers et al. (2007) en de Minimale Dataset (de Haan et al., 2019). In een enkel geval zijn de streefwaarden gebruikt zoals vermeld op de Eurofins BemestingsWijzer. Deze lopen echter erg uiteen, zelfs binnen hetzelfde perceel worden verschillende (berekende) waarden gerapporteerd voor de streefwaarden voor bijvoorbeeld de N-totaal en de P-totaal. Deze waarden worden daarom zo min mogelijk gebruikt.

\section{Stikstofoverschot}

Om een voldoende bodemvruchtbaarheidsniveau te bereiken of te behouden, moet men zorgen voor een goed evenwicht tussen aanvoer en verliezen. Een correcte bemesting houdt rekening met de vraag van de plant, de bestaande bodemvoorraad en de mineralisatie tijdens het jaar (Reubens et al., 2012). Het gewenste overschot bij een doelgerichte streefwaarde hangt daarom af van de gewenste stikstofbodemvoorraad. De doelgerichte streefwaarde sluit aan bij nitraatnorm, om de norm van $50 \mathrm{mg} / \mathrm{l}$ te behalen is het maximale stikstofoverschot voor zandgrond overgenomen uit de Haan et al. (2018). Voor de goede landbouwpraktijk zijn de normen uit de Buck et al. (2000) overgenomen, welke streven naar een halvering van de verliezen in het jaar 2000. De regionale stikstofoverschotten zijn bekend uit Agrimatie. Nader onderzoek naar de juiste streefwaarde voor stikstofoverschot op diverse grondsoorten in relatie tot de gewenste waterkwaliteit is gewenst.

\section{Fosfaatoverschot}

Het gewenste fosfaatoverschot is afhankelijk van de fosfaattoestand, de gewenste toestand en de grondsoort. Het vaststellen van het gewenste overschot is complex, omdat een overschot of tekort niet leidt tot een evenredige verandering in de bodemvoorraad, maar onder andere afhankelijk is van de onvermijdbare verliezen en de bindingscapaciteit van de bodem. Omgekeerd speelt ook tijd een rol, een evenwicht wordt bereikt na 5 tot 10 jaar. Het gewenste fosfaatoverschot of -tekort voor één jaar is daarom lastig te bepalen. Tonneijk en de Haan (2006) geven een eerste indicatie, deze is opgenomen als streefwaarde voor de beste landbouwpraktijk. Echter, een actualisatie en verfijning is wenselijk, bijvoorbeeld aan de hand van de studie van Amery et al. (2021). De relatie die zij opstellen tussen het fosfaatoverschot en de verandering in de bodem is echter gebaseerd op Europese veldproeven, en daarom vooralsnog niet overgenomen.

\section{Stikstofstatus}

Een doelgerichte streefwaarde voor de stikstofstatus is gericht op de instandhouding van de beschikbaarheid van kwalitatief hoogwaardige productiemiddelen, in dit geval een vruchtbare bodem. 
Deze streefwaarde heeft dan betrekking op het gewenste niveau van de stikstofreserve in de bodem om voldoende bodemvruchtbaarheid te garanderen. Deze waarde is echter moeilijk vast te stellen, en ontbreekt vooralsnog. Gemiddelden per grondsoort zijn bekend uit van den Elsen et al. (2020), deze waarden zijn opgenomen als regionale gemiddelden. Daarnaast hanteert Eurofins streefwaarden, voor klei-, zand- en dalgronden zijn deze respectievelijk 3110-4890, 3640-5310 en 5500-8380 kg N ha-1. Omdat deze zijn uitgedrukt in $\mathrm{kg} \mathrm{N}$ per hectare, zijn deze niet opgenomen.

\section{Fosfaatstatus}

Evenals voor stikstof is de gewenste waarde voor de instandhouding van een vruchtbare bodem niet bekend. Voor de fosfaatstatus horend bij de goede landbouwpraktijk is het bodemgericht advies overgenomen uit het Handboek Bodem en Bemesting, deze waarde is namelijk tot stand gekomen vanuit het oogpunt optimale opbrengsten voor bouwplannen met fosfaatbehoeftige gewassen.

\section{Kalistatus}

Met het oog op de kali-voorziening voor akkerbouwgewassen zijn streefwaarden en -trajecten bekend uit het Handboek Bodem en Bemesting, gebaseerd op veldproeven uit 1971 en 1984. Deze streefwaarden zijn uitgedrukt in het K-getal, waarbij onderscheid is gemaakt naar grondsoort en lutumgehalte, voor dekzand en dalgronden is dat 11 en voor zeeklei 18. Deze streefwaarden zijn opgenomen als goede landbouwpraktijk. Doelgerichte streefwaarden en regionale gemiddelden zijn niet bekend.

\section{Organische stof aanvoer}

Een doelgerichte streefwaarde voor de aanvoer van EOS is minimaal gericht op het in stand houden van het bodem organisch stofgehalte, en dus het compenseren van de jaarlijkse afbraak. Om tot een doelgerichte streefwaarde te komen, wordt een schatting gemaakt van de jaarlijkse afbraak van bodem organische stof. Als vuistregel wordt voor deze afbraak vaak $2 \%$ gehanteerd, terwijl deze onder de lokale omstandigheden sterk kan afwijken. Omdat de exacte afbraakpercentages niet per systeemproef bekend zijn, wordt er met kengetallen gerekend. Voor dalgrond wordt een afbraakpercentage van 0,5 gehanteerd, voor oude klei en zandgrond $2 \%$ en voor jonge klei 3\% (Schils, 2012). Een indicatie van de afbraak van organische stof wordt gegeven in Tabel 3-7. Voor de goede landbouwpraktijk wordt de vuistregel van $2000 \mathrm{~kg} \mathrm{EOS} \mathrm{ha-1}^{-1} \mathrm{jr}^{-1}$ gebruikt. De regionale aanvoer van EOS is door Conijn \& Lesschen (2015) per provincie berekend, deze is 1980, 1910 en $2240 \mathrm{~kg} \mathrm{ha}^{-1} \mathrm{jr}^{-1}$ in Drenthe, Flevoland en Limburg.

Tabel 3-7 Jaarlijkse afbraak van bodem organische stof

\begin{tabular}{|c|c|c|c|c|c|}
\hline $\begin{array}{l}\text { Bodem organische } \\
\text { stof } \\
(\%)\end{array}$ & $\begin{array}{l}\text { Organische stof in de } \\
\text { bouwvoor } \\
\left(\mathrm{kg} \mathrm{ha}^{-1}\right)\end{array}$ & & $\begin{array}{l}\text { Afbraak bij } \\
0,5 \% \\
\left(\mathrm{~kg} \mathrm{ha}^{-1} \mathrm{jr}^{-1}\right)\end{array}$ & $\begin{array}{l}\text { Afbraak bij } \\
2 \% \\
\left(\mathrm{~kg} \mathrm{ha}^{-1} \mathrm{jr}^{-1}\right)\end{array}$ & $\begin{array}{l}\text { Afbraak bij } \\
3 \% \\
\left(\mathrm{~kg} \mathrm{ha}^{-1} \mathrm{jr}^{-1}\right)\end{array}$ \\
\hline & & 35000 & 175 & 700 & 1050 \\
\hline & & 70000 & 350 & 1400 & 2100 \\
\hline & & 105000 & 525 & 2100 & 3150 \\
\hline & & 140000 & 700 & 2800 & 4200 \\
\hline & & 175000 & 875 & 3500 & 5250 \\
\hline & & 210000 & 1050 & 4200 & 6300 \\
\hline & & 245000 & 1225 & 4900 & 7350 \\
\hline & & 280000 & 1400 & 5600 & 8400 \\
\hline & & 315000 & 1575 & 6300 & 9450 \\
\hline & & 350000 & 1750 & 7000 & 10500 \\
\hline
\end{tabular}

\section{Organisch stofgehalte}

Het opstellen van streefwaarden voor een bodem organisch stofgehalte is niet eenvoudig, omdat de relaties tussen het bodem organisch stofgehalte en bodemeigenschappen complex zijn. Op basis van jarenlange proefveldwerking en praktijkervaring hebben Reubens et al. (2012) minimumwaarden opgesteld die een goede bodemvruchtbaarheid beogen. Deze waarden zijn genomen als doelgerichte streefwaarden. Als algemene vuistregel voor een minimaal organisch stofgehalte wordt veelal het volgende aangehouden: 1,5+0,1*lutum\% (de Haan et al., 2019). Deze benadering wordt opgenomen als streefwaarde voor de beste landbouwpraktijk. In de BLN 1.0 zijn referentiewaarden overgenomen uit Rutgers et al. (2007), deze range is erg ruim, en loopt op kleigronden uiteen van 1,6 tot 3,6\% en op zandgrond van 3,3 tot $16,2 \%$. Op basis van de studie van van Tol-Leenders et al. (2019) zijn de referentiewaarden nader gespecificeerd (van den Elsen et al., 2020). Deze range is opgenomen als regionale gemiddelden. 


\section{HWC}

Voor de HWC zijn referentiewaarden bekend uit de BLN, welke zijn overgenomen als regionale gemiddelden. Deze referentiewaarden lopen uiteen van 500 tot $2000 \mathrm{mg} \mathrm{C} \mathrm{kg}^{-1}$ grond op zandgronden en is voor kleigrond vastgesteld op $500 \mathrm{mg} \mathrm{C} \mathrm{kg}^{-1}$. Uit een langjarige proef op kleigrond bleek na toediening van verschillende organische mestsoorten de HWC uit een te lopen tussen de 251 en $358 \mathrm{mg}$ $\mathrm{C} \mathrm{kg}^{-1}$ (Zanen et al., 2008). Mogelijkerwijs valt de range van de referentiewaarden zoals gehanteerd in de BLN lager uit. Doelgerichte streefwaarden of streefwaarden voor een goede landbouwpraktijk zijn niet bekend. Meer onderzoek naar goede streefwaardes voor HWC is nodig.

\section{Indringingsweerstand}

De streefwaarde voor de goede landbouwpraktijk is overgenomen uit de BLN, deze waarde is gebaseerd op de gemiddelde weerstand die wortels nog kunnen weerstaan ( $<3 \mathrm{MPa}$ ). Boven 2,5 $-3 \mathrm{MPa}$ wordt de wortelgroei belemmerd. De grenswaarde voor de indringingsweerstand is sterk afhankelijk van het vochtgehalte van de bodem, het vermogen van een gewaswortel om door te dringen in het bodemprofiel, vandaar dat er in de BLN is voorgesteld een waarde tussen 2 en 3 op te nemen (Hanegraaf et al., 2019). Soms kunnen wormgangen dienen als wortelgang en pas boven 4-5 MPa remming van wortelgroei optreden (de Haan et al., 2019). Een doelgerichte streefwaarde, waarin rekening gehouden dient te worden met het vochtgehalte en gewassoort, is niet vastgesteld. Ook regionale gemiddelden zijn niet bekend.

\section{Droge bulkdichtheid}

De droge bulkdichtheid is erg afhankelijk van de bodemtextuur (van de Elsen et al., 2019), voor zand-, klei-, leem- en veengronden is de gemiddelde droge bulkdichtheid 1,6, 1,1, 1,1, en $0,25 \mathrm{~g} / \mathrm{cm}^{3}$ respectievelijk. Deze waarden zijn overgenomen als regionale gemiddelden. In de BLN werden aanvankelijk streefwaarden vastgesteld welke variëren tussen de 1,4 en 1,75 g/cm afhankelijk van het kleigehalte (Hanegraaf et al., 2019). In de versie 1.1 zijn deze waarden vervangen door de waarden die volgen uit de statistische analyse uitgevoerd door Tol-Leenders et al. (2019). De streefwaarden voor de goede landbouwpraktijk volgen uit de BLN versie 1.1. In Reubens et al. (2012) zijn referentiewaarden benoemd van 1,3-1,7 en 1,1-1,6 g/ $\mathrm{cm}^{3}$ voor zand- en kleigronden respectievelijk, deze waarden worden niet opgenomen als streefwaarden maar ondersteunen mogelijk de interpretatie van de meetwaarden. Doelgerichte streefwaarden zijn niet vastgesteld.

\section{Potentieel mineraliseerbare stikstof (PMN)}

Voor zowel zand- als kleigronden hanteert Eurofins een streefwaarde tussen de 60-80 mg N per kg, deze waarde is opgenomen als streefwaarde voor een goede landbouwpraktijk.

\subsubsection{Emissies en leefomgeving}

\section{Bodembedekking}

Een optimale bodembedekking hangt af van factoren zoals onkruiddruk, aaltjessituatie en de gevoeligheid van de bodem voor wind- en watererosie. Onderbouwde streefwaarden zijn voor deze indicator niet bekend.

\section{Gebruik gewasbeschermingsmiddelen}

Het maximale gebruik van gewasbeschermingsmiddelen is per product en gewas bepaald in de wettelijke gebruiksvoorschriften. Het gebruik van actieve stoffen wordt bijgehouden door het CBS, gemiddelden van het gebruik van actieve stoffen per hectare in de Nederlandse akkerbouw zijn beschikbaar (CLO) en zijn gebruikt als regionaal gemiddelde. Het gemiddeld gebruik van actieve stof per teelt zijn als volgt: consumptieaardappel: $12,8 \mathrm{~kg} \mathrm{ha}^{-1}$; erwt: $1,5 \mathrm{~kg} \mathrm{ha}^{-1}$; gras(klaver) $0,7 \mathrm{~kg} \mathrm{ha}^{-1}$; kool: $3,7 \mathrm{~kg} \mathrm{ha}^{-1}$; lelie: 124,5 kg ha-1; peen: $3,3 \mathrm{~kg} \mathrm{ha}^{-1}$; pootaardappel: $20 \mathrm{~kg} \mathrm{ha}^{-1}$; prei: 5,2 kg ha-1; snijmais: $1,1 \mathrm{~kg} \mathrm{ha}^{-1}$; suikerbiet: $3,9 \mathrm{~kg} \mathrm{ha}{ }^{-1}$; ui: $16,5 \mathrm{~kg} \mathrm{ha}^{-1}$; bonen: $3,4 \mathrm{~kg} \mathrm{ha}^{-1}$; zetmeelaardappel: $11,6 \mathrm{~kg} \mathrm{ha}^{-1}$; zomergerst: $1,2 \mathrm{~kg} \mathrm{ha}^{-1}$; zomertarwe: $1,4 \mathrm{~kg} \mathrm{ha}^{-1}$.

\section{N-min najaar}

De nitraatnorm bedraagt $50 \mathrm{mg}$ nitraat per liter. Op droge zandgronden wordt deze nitraatnorm doorgaans gehaald bij een $\mathrm{Nmin}(0-90 \mathrm{~cm})$ van $20 \mathrm{~kg} \mathrm{ha}^{-1}$, vanwege de grote variatie is pas bij een $\mathrm{Nmin}$ van meer dan $75 \mathrm{~kg} \mathrm{ha}^{-1}$ met zekerheid te zeggen dat deze norm overschreden wordt (Hoving, 2005). In de studie van van Enckevort et al. (2001) wordt een kritische waarde vastgesteld op 44 en $88 \mathrm{~kg} \mathrm{~N}$ $\mathrm{ha}^{-1}(0-100 \mathrm{~cm})$ voor zand- en kleigronden respectievelijk. Omdat de Nmin doorgaans gemeten wordt op $0-90 \mathrm{~cm}$, moeten deze waarden gecorrigeerd worden. Om stikstofverliezen en daarmee uitspoeling te voorkomen wordt er gestreefd naar (een zo hoog mogelijke N-efficiëntie en) een zo laag mogelijke $\mathrm{N}-\mathrm{min}(0-90 \mathrm{~cm})$ in het najaar. Hoewel niet realistisch, wordt $0 \mathrm{~kg} \mathrm{~N}^{-1}$ gesteld op $100 \%$. De kritische 


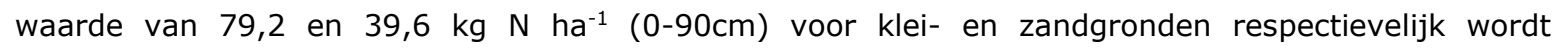
gelijkgesteld aan $0 \%$.

\subsubsection{Circulariteit en grondstoffen}

\section{Water verbruik}

Voor deze indicator zijn geen onderbouwde streefwaarden of regionale gemiddelden bekend.

\section{Diesel verbruik}

Voor deze indicator is nog geen streefwaarde vastgesteld.

\section{Aandeel niet kunstmest stikstof}

Gemiddeld genomen over de Nederlandse akkerbouwbedrijven kwam in 2018 46\% en 62\% van de totale aangevoerde stikstof uit organische mest, respectievelijk voor klei- en zandgronden (Agrimatie, 2021c). Het streeftraject is daarom vastgesteld op respectievelijk $46-100 \%$ en $62-100 \%$ voor klei- en zandgronden.

\section{Aandeel niet kunstmest fosfaat}

Gemiddeld genomen over de Nederlandse akkerbouwbedrijven kwam in 2019 84\% en $94 \%$ van het totale aangevoerde fosfaat uit organische mest, respectievelijk voor klei- en zandgronden (Agrimatie, 2021-d). Het streeftraject is daarom vastgesteld op respectievelijk $84-100 \%$ en $94-100 \%$ voor klei- en zandgronden. 


\section{$4 \quad$ Systeemprestaties}

\subsection{Bodemkwaliteit Veenkoloniën}

\subsubsection{Achtergrond en opzet van de systeemproef}

In de systeemproef Bodemkwaliteit Veenkoloniën (BKV) worden een vijftal maatregelen gericht op het verbeteren van de bodemkwaliteit vergeleken met de standaard werkwijze, in een vierjarige veenkoloniale akkerbouwvruchtwisseling (zetmeelaardappel - suikerbiet - zetmeelaardappel zomergerst). Deze maatregelen bestaan uit het telen van tagetes, het toedienen van compost, het sturen op optimale $\mathrm{Ca} / \mathrm{Mg}$-verhoudingen en het toepassen van steenmeel, ook een combinatie van deze maatregelen is onderzocht. Daarnaast zijn in elk van deze maatregelen twee verschillende grondbewerkingen toegepast, namelijk spitten en NKG. De resultaten van de eerste vier jaar van de proef worden omschreven in de Haan et al. (2020). In het testen van de systeemprestaties worden de twee uiterste maatregelen opgenomen als 'systeem', namelijk Standaard-spitten en Combi-NKG. In het object Standaard-spitten wordt de hoofdgrondbewerking voor de teelt uitgevoerd met een roterende spitmachine met een werkdiepte van $30 \mathrm{~cm}$, op reguliere wijze bemest en gerststro afgevoerd. In het object Combi-NKG wordt de hoofdgrondbewerking voor de teelt uitgevoerd met een 5-tands ondergrondwoeler op $40 \mathrm{~cm}$ diepte gevolgd door een vastetandcultivator op $25 \mathrm{~cm}$ diepte en een vorenpakker. Daarnaast wordt er $\mathrm{Ca}, \mathrm{Mg}$ en $\mathrm{K}$ toegepast om toe te werken naar de juiste verhoudingen in de bodem, 20 ton $\mathrm{ha}^{-1} \mathrm{jr}^{-1}$ groencompost aangevoerd in de aardappelen en suikerbiet, en tot en met 20173 ton bioliet en 3 ton zeoliet ha-1 $\mathrm{jr}^{-1}$ aangevoerd. Bovendien wordt in het object Combi-NKG de teelt van zomergerst eens in de acht jaar vervangen door Tagetes, in 2019 is er in beide objecten zomergerst geteeld.

\subsubsection{Systeemprestaties}

De prestaties van beide systemen zijn weergegeven in Tabel 4-1 en Figuur 4-1. HWC en bulkdichtheid zijn in 2019 in BKV niet bepaald, en daarom niet opgenomen in Tabel 4-1 en Figuur 4-1. De resultaten worden hieronder kort besproken.

In 2019 waren de opbrengsten van beide systemen hoger dan het regionaal gemiddelde, de opbrengst van Combi-NKG is zelfs hoger dan de goede landbouwpraktijk. De opbrengst van het belangrijkste gewas, de zetmeelaardappelen, was met 44-54 ton ha-1 hoger dan de goede landbouwpraktijk, welke vastgesteld is op 41 ton $\mathrm{ha}^{-1}$. De verschillen in opbrengst tussen de Combi-NKG en Standaard-spitten zijn aanzienlijk (10, 4 en 3 ton ha-1 respectievelijk voor de twee zetmeelaardappelen en suikerbieten), maar komen beperkt tot uiting in de systeemprestatie in Tabel 2-8.

De kwaliteit van de producten is voor beide systemen erg hoog, ruim boven het regionaal gemiddelde en de goede landbouwpraktijk. Deze hoge prestatie is niet toe te schrijven aan één van de gewassen, de kwaliteit van elk van de afzonderlijke gewassen was hoger dan de goede landbouwpraktijk.

Dat het stikstof- en fosfaatoverschot in het object Combi-NKG hoger was dan in Standaard-spitten is direct te relateren aan de aanvoer van compost. De hogere opbrengst in het object Combi-NKG en daarmee verhoogde afvoer, valt in het niet bij de hoge aanvoer. Het is dan ook niet verrassend dat het stikstof- en fosfaatoverschot bij Combi-NKG hoger was dan alle gestelde streefwaarden. Ook zonder compost zijn de nutriëntenoverschotten aan de hoge kant. Wat betreft stikstof was het overschot groter dan er vanuit de goede landbouwpraktijk noodzakelijk geacht wordt, maar minder hoog dan het regionaal gemiddelde. Het is opvallend dat het grote verschil in het stikstofoverschot tussen de twee objecten niet terug te zien is in de hoeveelheid gemeten minerale stikstof in de bodem in het najaar. Voor fosfaat werd er meer dan nodig aangevoerd om de huidige toestand te handhaven, de huidige toestand valt namelijk binnen het streeftraject. 
Door de aanvoer van compost bij het object Combi-NKG is het aandeel aangevoerde stikstof van organische bron hoger dan wanneer er standaard wordt bemest zoals bij het object Standaard-spitten. In beide systemen is een relatief klein deel van de stikstofbemesting van organische oorsprong, in vergelijking tot het Nederlands gemiddelde voor zandgronden. Gemiddelden specifiek voor de regio Veenkoloniën zijn niet beschikbaar. In tegenstelling tot stikstof, wordt er geen fosfaat in kunstmestvorm toegediend. In het aandeel organische fosfaat is daarom geen verschil tussen beide objecten.

De fosfaattoestand van beide objecten is gelijk, en ruim lager dan het regionaal gemiddelde. Dit is opvallend gezien de ruime overschotten op de balans, dat er geen verschil in toestand tussen beide objecten was is mogelijk te verklaren doordat het organisch gebonden fosfaat uit compost beperkt wordt gemeten met het $\mathrm{Pw}$-getal ${ }^{\circ}$, de bodemvoorraad (uitgedrukt in P-Al), was bij het object Combi-NKG hoger dan bij Standaard-spitten. Dat de stikstofstatus en het K-getal bij Combi-NKG hoger zijn dan bij Standaard-spitten is toe te schrijven aan de aanvullende bemesting met compost en kali. De stikstofstatus van beide objecten is laag in vergelijking tot de streefwaarden.

Het is opvallend dat de hoge aanvoer van EOS in object Combi-NKG beperkt tot uiting komt in de activiteit van het bodemleven, wat gemeten wordt door middel van PMN. Deze waarde is bij Combi-NKG iets hoger dan bij Standaard-spitten, al blijkt het verschil met name tussen de percelen groot. De relatief hoge aanvoer van EOS in het object Combi-NKG komt niet tot uiting in het bodem organisch stofgehalte, in de periode 2014-2019 is het bodem organisch stofgehalte in beide objecten gedaald.

In beide objecten is er geen sprake van wortelbelemmering in de laag $30-40 \mathrm{~cm}$, de indringingsweerstand in het NKG-object is lager dan bij spitten.

Gezien de focus van de proef zijn een aantal aspecten van het management constant gehouden voor beide systemen (zoals beregening, gebruik van gewasbeschermingsmiddelen en zaai- en oogsttijdstippen), waardoor deze systeemprestaties gelijk zijn en verschil in eigenschappen niet tot uiting komen (bijvoorbeeld in de vochtvoorziening of weerbaarheid van het gewas). Het gebruik van gewasbeschermingsmiddelen in beide systemen is overigens hoog in vergelijking tot het praktijk gemiddelde.

Het grote verschil tussen de twee objecten is de bemesting en de grondbewerking, deze verschillen komen tot uiting in gerelateerde parameters zoals het stikstof- en fosfaatoverschot en de EOS-aanvoer (zie Tabel 4-1). Ook bij de afhankelijke variabelen wordt het verschil in management zichtbaar, zoals bij het bodem organisch stof percentage, de indringingsweerstand, de kalistatus, de stikstofstatus en de opbrengst. Enkel bij de fosfaattoestand is er geen verschil. In deze analyse zijn enkel gegevens van 2019 opgenomen. Dit jaar werd gekenmerkt door een relatief droog voorjaar en zomer, waarbij het mogelijk effect van het gevoerde management goed zichtbaar worden. Mogelijk zijn de verschillen minder groot in overige jaren. Trade-offs worden beperkt zichtbaar, mogelijkerwijs komen deze wel tot uiting in het saldo of het dieselgebruik.

\footnotetext{
${ }^{\circ}$ Met het pw-getal wordt de direct beschikbare

hoeveelheid fosfaat in de bodem gemeten, het is een intensiteitsparameter.
} 
Tabel 4-1 Systeemprestaties van Standaard-spitten en Combi-NKG in de systeemproef Bodemkwaliteit Veenkoloniën.

\begin{tabular}{|c|c|c|c|c|c|c|c|}
\hline nr. & Indicator & Eenheid & $\begin{array}{l}\text { Doelgerichte } \\
\text { streefwaarde }\end{array}$ & $\begin{array}{l}\text { Goede } \\
\text { landbouwpraktijk }\end{array}$ & $\begin{array}{l}\text { Regionaal } \\
\text { gemiddelde }\end{array}$ & $\begin{array}{l}\text { Standaard- } \\
\text { spitten }\end{array}$ & $\begin{array}{l}\text { Combi- } \\
\text { NKG }\end{array}$ \\
\hline 1 & Opbrengst & $\%$ & 100 & 67 & 58 & 63 & 69 \\
\hline 2 & Kwaliteit van product & $\%$ & 100 & 85 & 78 & 92 & 90 \\
\hline 3 & Saldo & & & & & & \\
\hline 4 & Stikstofoverschot & $\mathrm{kg} \mathrm{N} / \mathrm{ha}$ & 60 & 70 & 94 & 84 & 211 \\
\hline 5 & Fosfaatoverschot & kg P2O5/ha & 0 & 0 & 10 & 36 & 141 \\
\hline 6 & Stikstofstofstatus & $\mathrm{mg} / \mathrm{kg}$ & & & $1324-4408$ & 2657 & 2691 \\
\hline 7 & Fosfaatstatus & pw-getal & 30 & 30 & 78 & 37 & 37 \\
\hline 8 & Kalistatus & K-getal & & 11 & & 8 & 11 \\
\hline 9 & EOS aanvoer & $\mathrm{kg} \mathrm{EOS/ha}$ & $1838-1960$ & 2000 & 1980 & 1440 & 5081 \\
\hline 10 & OS \% & $\%$ & $>1,90-3,28$ & $>1,6$ & $4,5-15,8$ & 10,5 & 11,2 \\
\hline 11 & HWC & $\mathrm{mg} / \mathrm{kg}$ & & & $500-2000$ & & \\
\hline 12 & Indringingsweerstand & Mpa & & $<3$ & & 2,5 & 2,1 \\
\hline 13 & bulkdichtheid & $\mathrm{kg} / \mathrm{m} 3$ & & $1,2-1,51$ & $0,53-1,75$ & & \\
\hline 14 & PMN & $\mathrm{mg} / \mathrm{kg}$ & & $60-80$ & & 55 & 57 \\
\hline 17 & Bodembedekking & $\%$ & 100 & & & 54 & 54 \\
\hline 18 & Gewasbescherming & $\mathrm{kg}$ a.s./ha & 0 & 6,5 & 7,1 & 9,5 & 9,5 \\
\hline 19 & Nmin najaar & $\mathrm{kg} \mathrm{N} / \mathrm{ha}$ & & 40 & & 49* & 42* \\
\hline 21 & Beregening & $\mathrm{mm} /$ ton & 0 & & & 0,4 & 0,4 \\
\hline 24 & Diesel & & & & & & \\
\hline 25 & Organische-N & $\%$ & 100 & & 62 & 45 & 60 \\
\hline 26 & Organische-P2O5 & $\%$ & 100 & & 95 & 100 & 100 \\
\hline
\end{tabular}

* Nmin najaar gemeten in de laag $0-60 \mathrm{~cm}$.

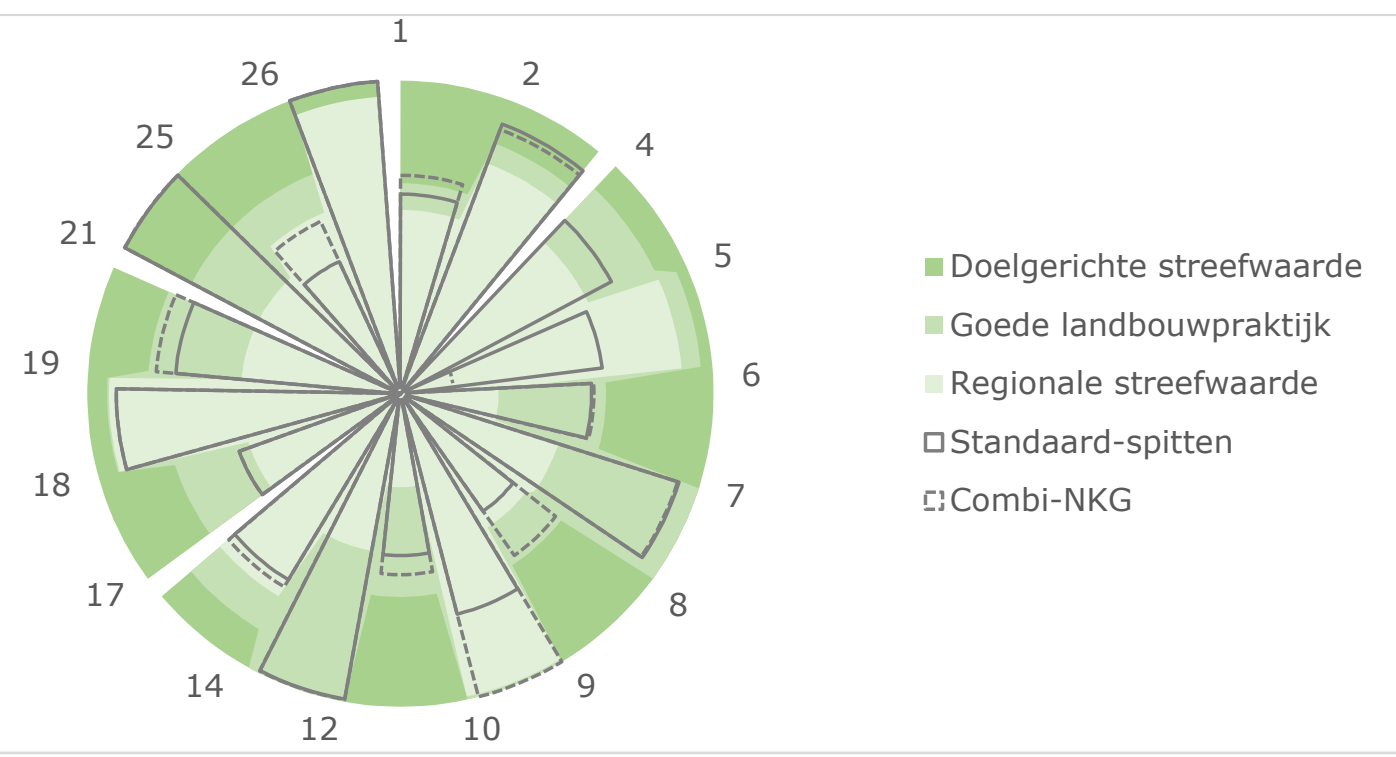

Figuur 4-1 BKV: visuele weergave van de systeemprestaties van de opbrengst (1), kwaliteit (2), stikstofoverschot (4), fosfaatoverschot (5), stikstofstatus (6), fosfaatstatus (7), kalistatus (8), EOSaanvoer (9), OS\% (10), indringingsweerstand (12), PMN (14), bodembedekking (17),

gewasbeschermingsmiddelen (18), Nmin najaar (19), beregening (21), aandeel organische stikstof (25) en aandeel organische fosfaat (26).

\subsection{Bodemkwaliteit op zand}

\subsubsection{Achtergrond en opzet van de systeemproef}

In de systeemproef Bodemkwaliteit op Zand (BKZ) zijn in een 6-jarige vruchtwisseling twee gangbare bedrijfssystemen aangelegd met een verschillend organisch stof beheer. Doel van deze proef is om te zien wat het effect is van organische stof aanvoer op de opbrengst, bodemkwaliteit, nutriëntenbalansen, stikstofstromen en -uitspoeling. De resultaten van de periode 2011-2016 zijn omschreven in de Haan et al. (2018). De twee systemen, 'Standaard' en 'Laag', zijn opgenomen om de huidige set aan indicatoren op te testen. In Standaard is een gemiddelde aanvoer van organische stof nagestreefd, 
zowel met dierlijke mest als gewasresten en groenbemesters. De verwachting is dat de bodemkwaliteit bij dit management gehandhaafd blijft. In Laag is een lage aanvoer van organische stof nagestreefd door nagenoeg geen organische stof met dierlijke mest aan te voeren. De overige teelthandelingen waren gelijk voor beide systemen.

\subsubsection{Systeemprestaties}

De prestaties van beide systemen zijn weergegeven in Tabel 2-9 en Figuur 2-2. De resultaten worden hieronder kort besproken.

De opbrengsten zijn voor beide systemen vergelijkbaar met het regionaal gemiddelde. Dit komt met name door een slechte opbrengst van erwt. Het verschil tussen de systemen voor zowel de opbrengst als de kwaliteit is beperkt, de kwaliteit van de producten was bij beide systemen redelijk. Het verschil in management tussen de systemen is bij enkele andere indicatoren wel goed zichtbaar, waaronder het stikstofoverschot, stikstofstatus, fosfaatstatus, EOS-aanvoer en het aandeel niet-kunstmest in de bemesting.

Bij de twee systemen is er gestuurd op een gelijke aanvoer van werkzame stikstof. Omdat er bij de berekening van het stikstofoverschot uitgegaan is van de totale gehalten, is er een duidelijk verschil tussen de systemen, het overschot was groter bij Standaard dan bij Laag. Het stikstofoverschot bij systeem Laag lag ruim onder het regionaal gemiddelde en de goede landbouwpraktijk. Het stikstofoverschot bij Standaard was vergelijkbaar met de goede landbouwpraktijk. Het verschil in het stikstofoverschot tussen de twee systemen komt ook terug in de bodem stikstofvoorraad, welke hoger was voor Standaard dan voor Laag. Voor beide systemen was de bodem stikstofvoorraad vrij laag, bij systeem Laag lag deze zelfs onder de referentiewaarde. In Tabel 4-2 wordt zichtbaar dat de N-min in het najaar niet direct gerelateerd is aan de berekende stikstofbalans, mogelijk geeft een stikstofbalans gebaseerd op de werkzame stof een beter beeld.

Ook op fosfaat wordt strak gestuurd in deze proef. De afvoer van fosfaat was bij beide systemen gelijk, het grote verschil in het fosfaatoverschot komt door het verschil in bemesting, welke direct voortkomt uit het verschil in de fosfaattoestand. Het Pw-getal bij Laag is 38 (klasse ruim voldoende) ten opzichte van 49 bij Standaard (klasse hoog). Het verschil in fosfaattoestand is niet toe te schrijven aan de verschillende systemen, bij aanvang van de proef in 2011 was er al een ruim verschil in de fosfaattoestand van de twee systemen (Pw-getal van 39 en 54 respectievelijk voor Laag en Standaard).

Zoals beoogd is de aanvoer van organische stof bij het systeem Standaard vergelijkbaar met het regionaal gemiddelde, en is de aanvoer van organische stof relatief laag bij systeem Laag. Geheel in lijn is ook het aandeel stikstof en fosfaat uit organische mest bij systeem Laag lager dan het regionaal gemiddelde. Opvallend is dat dit aandeel ook bij systeem Standaard lager is dan het regionaal gemiddelde. Dat het gedeelte organische stikstof in de bemesting bij beide systemen vergelijkbaar is terwijl de aanvoer van organische stof erg verschilt komt omdat er in het systeem Laag minerale concentraten zijn toegepast, welke een laag gehalte organische stof hebben.

Met het verschil in aanvoer van organische stof is het niet verrassend dat het microbiële bodemleven, gemeten met PMN, bij systeem Laag lager is dan bij Standaard, al scoren beide systemen laag in vergelijking tot de streefwaarde.

Gezien de focus van de proef zijn een aantal aspecten van het management constant gehouden voor beide systemen (zoals beregening, gebruik van gewasbeschermingsmiddelen en zaai- en oogsttijdstippen), waardoor deze systeemprestaties gelijk zijn en verschil in eigenschappen niet tot uiting komen (bijvoorbeeld in de vochtvoorziening of weerbaarheid van het gewas). Omdat beregening uitgedrukt is in $\mathrm{mm}$ per ton gewasopbrengst, is er vanwege een verschil in gewasopbrengsten een minimaal verschil zichtbaar. Het gebruik van gewasbeschermingsmiddelen in beide systemen is hoog in vergelijking tot het regionaal gemiddelde.

Trade-offs worden beperkt zichtbaar. Het doel van de proef is een strikte bemesting met een laag $\mathrm{N}$ overschot. Uit Tabel 4-2 is af te leiden dat het gelukt is om te komen tot een relatief laag overschot op de stikstofbalans en opbrengsten welke overeen komen met het regionaal gemiddelde. In dit geval is er dus geen sprake van een trade-off, maar van een redelijk tot goede prestatie op beide componenten. 
Tabel 4-2 Systeemprestaties van de systemen 'LAAG' en 'STANDAARD' in de systeemproef Bodemkwaliteit op Zand.

\begin{tabular}{|c|c|c|c|c|c|c|c|}
\hline nr. & Indicator & Eenheid & $\begin{array}{l}\text { Doelgerichte } \\
\text { streefwaarde }\end{array}$ & \begin{tabular}{|l|} 
Goede \\
landbouwpraktijk
\end{tabular} & $\begin{array}{l}\text { Regionaal } \\
\text { gemiddelde }\end{array}$ & STANDAARD & LAAG \\
\hline 1 & Opbrengst & $\%$ & 100 & 81 & 65 & $\begin{array}{r}66 \\
\end{array}$ & 68 \\
\hline 2 & Kwaliteit van product & $\%$ & 100 & 92 & 82 & 84 & 87 \\
\hline 3 & Saldo & & & & & & \\
\hline 4 & Stikstofoverschot & $\mathrm{kg} \mathrm{N} / \mathrm{ha}$ & 50 & 70 & 94 & 68 & 55 \\
\hline 5 & Fosfaatoverschot & kg P2O5/ha & 0 & 0 & 10 & -9 & 26 \\
\hline 6 & Stikstofstofstatus & $\mathrm{mg} / \mathrm{kg}$ & & & $1243-1841$ & 1252 & 1128 \\
\hline 7 & Fosfaatstatus & pw-getal & 30 & 30 & 78 & 49 & 38 \\
\hline 8 & Kalistatus & K-getal & & 11 & & 11 & 12 \\
\hline 9 & EOS aanvoer & $\mathrm{kg} \mathrm{EOS/ha}$ & 2590-2940* & 2000 & 2240 & 2287 & 1287 \\
\hline 10 & OS \% & $\%$ & $>1,90-3,28$ & 1,6 & $3,5-5,3$ & 4,2 & 3,7 \\
\hline 11 & HWC & $\mathrm{mg} / \mathrm{kg}$ & & & $500-2000$ & & \\
\hline 12 & Indringingsweerstand & Mpa & & $<3$ & & & \\
\hline 13 & bulkdichtheid & $\mathrm{kg} / \mathrm{m} 3$ & & $1,2-1,51$ & $1,14-1,64$ & & \\
\hline 14 & PMN & $\mathrm{mg} / \mathrm{kg}$ & & $60-80$ & & 15 & 8 \\
\hline 17 & Bodembedekking & $\%$ & 100 & & & 74 & 74 \\
\hline 18 & Gewasbescherming & kg a.s./ha & 0 & 6,5 & 4,2 & 5,7 & 5,7 \\
\hline 19 & Nmin najaar & $\mathrm{kg} \mathrm{N} / \mathrm{ha}$ & & 39,6 & & 21 & 45 \\
\hline 21 & Beregening & $\mathrm{mm} /$ ton & 0 & & & 7 & 8 \\
\hline 24 & Diesel & & & & & & \\
\hline 25 & Organische- $\mathrm{N}$ & $\%$ & 100 & & 62 & 47 & 44 \\
\hline 26 & Organische-P2O5 & $\%$ & 100 & & 95 & 69 & 23 \\
\hline
\end{tabular}

* Uitgaande van een jaarlijkse afbraak van $2 \%$.

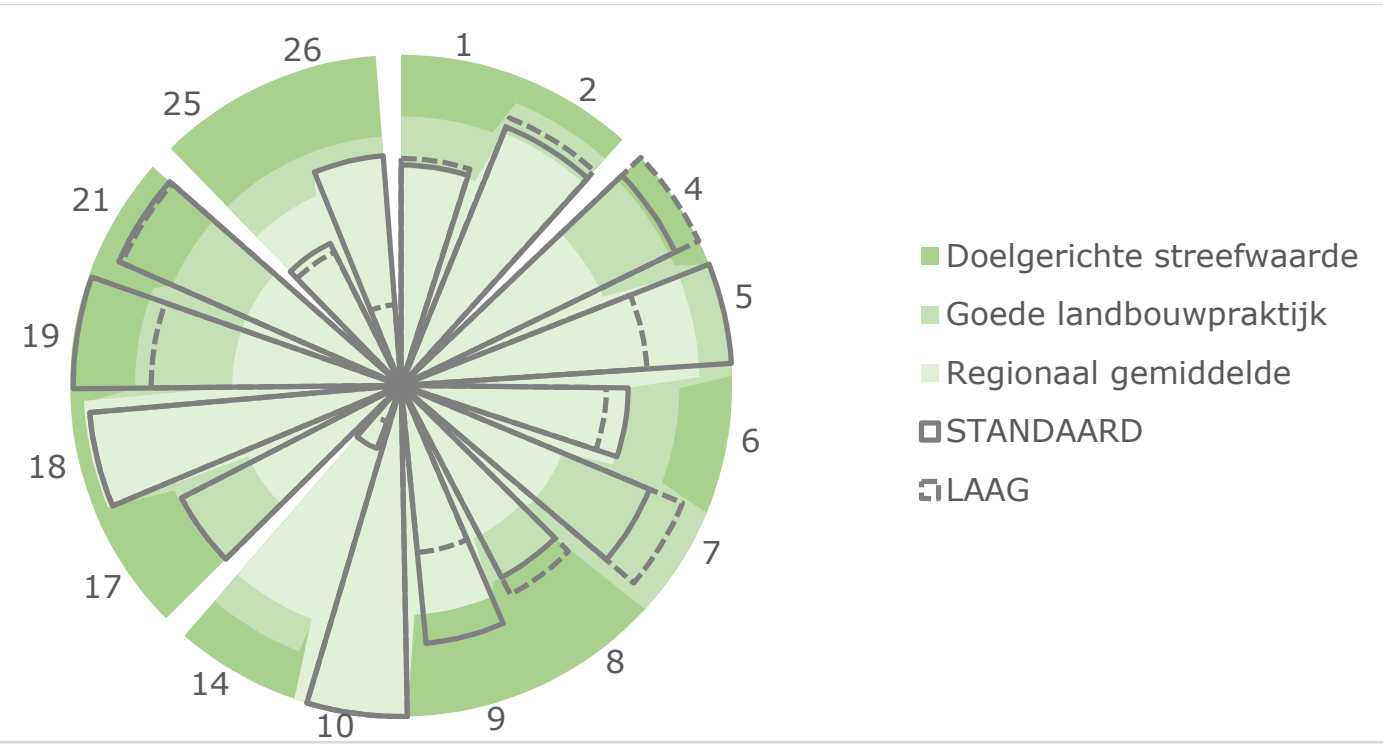

Figuur 4-2 BKZ: visuele weergave van de systeemprestaties van de opbrengst (1), kwaliteit (2), stikstofoverschot (4), fosfaatoverschot (5), stikstofstatus (6), fosfaatstatus (7), kalistatus (8), EOSaanvoer (9), OS\% (10), PMN (14), bodembedekking (17), gewasbeschermingsmiddelen (18), Nmin najaar (19), beregening (21), aandeel organische stikstof (25) en aandeel organische fosfaat (26). 


\section{$4.3 \quad$ BASIS}

\subsubsection{Achtergrond en opzet van de systeemproef}

In Lelystad is in 2008 een proef aangelegd om de effecten van verschillende grondbewerkingstype te onderzoeken. Hiervoor zijn drie verschillende vormen van grondbewerking aangelegd, op twee gangbare percelen en drie biologische percelen. Bij de standaard grondbewerking (PL) wordt geploegd op een diepte van $23-25 \mathrm{~cm}$. Bij de tussenvorm (NKG+) wordt niet geploegd, maar gewoeld op een diepte van $18-20 \mathrm{~cm}$. Bij de minimale grondbewerking (NKG-) wordt niet geploegd. In deze analyse zijn de grondbewerkingssystemen ploegen en NKG+ van de gangbare percelen opgenomen. De gangbare percelen hebben een vruchtwisseling met pootaardappel, suikerbiet, zomergerst en zaaiui of conservenerwt. Omdat het gangbare systeem een vruchtwisseling van 4 jaar kent en slechts 2 percelen heeft, is er niet voor elk gewas data beschikbaar van 2019. In 2019 werd er conservenerwt en pootaardappel geteeld, voor suikerbiet werd data gebruikt uit 2017 en voor zomergerst uit en voor ui uit 2018.

\subsubsection{Systeemprestaties}

De prestaties van beide systemen zijn weergegeven in en. De resultaten worden hieronder kort besproken.

Gezien de opzet van de proef, zijn de opbrengstgegevens niet voor elk gewas van 2019 beschikbaar. De opbrengstgegevens van het laatst geteelde jaar opgenomen. Omdat in beide systemen elk jaar hetzelfde gewas is geteeld, is een vergelijking tussen de systemen mogelijk. Gemiddeld over de gewassen was de opbrengst van beide systemen vergelijkbaar met het regionaal gemiddelde. Voor beide systemen was de opbrengst van de suikerbiet en ui hoger dan de goede landbouwpraktijk, van de zomergerst vergelijkbaar met het regionaal gemiddelde en van de pootaardappels en erwten was de opbrengst minder dan het regionaal gemiddelde. Het verschil tussen de systemen komt door het verschil in opbrengst van de pootaardappels, deze waren 33 en 30 ton ha-1 respectievelijk voor 'Ploegen' en 'NKG+'. Tussen de objecten komt geen verschil in kwaliteit naar voren, de kwaliteit van de geoogste gewassen is voor beide systemen goed in vergelijking tot de referentiewaarden. Het percentage schurft op de pootaardappels is relatief laag (2\%), het suikergehalte in de bieten relatief hoog $(20 \%)$ en de tarra bij de ui relatief laag $(0,7 \%)$.

BASIS kent een strikte stikstofbemesting, met een gemiddelde opbrengst resulteert deze lage aanvoer in een negatief stikstofbodemoverschot. De strikte bemesting heeft geleid tot een lage stikstofbodemvoorraad, deze valt namelijk voor beide objecten onder de regionale referentiewaarden. Bij een gelijke bemesting en vergelijkbare afvoer voor beide systemen is de stikstofbodemvoorraad bij 'NKG+' hoger dan voor 'Ploegen'. Deze stikstofbodemvoorraad heeft betrekking op de laag $0-30 \mathrm{~cm}$. Ntotaal wordt in BASIS ook in de lagen 0-15 en $15-30 \mathrm{~cm}$ gemeten, waarin mogelijk verschillen tussen de objecten beter tot uiting komen. De minerale stikstof gemeten in het najaar in de laag $0-90 \mathrm{~cm}$ laat geen verschil zien tussen de objecten.

Ook voor fosfaat geldt dat er strikt wordt bemest, dit resulteert in een fosfaatoverschot van 7 en $8 \mathrm{~kg}$ P2O5 ha-1 respectievelijk voor 'Ploegen' en 'NKG+'. Dit overschot op de fosfaatbalans is waarschijnlijk onvoldoende om de lage fosfaattoestand te verhogen. De kalitoestand valt, net als de stikstofstatus, binnen het streeftraject.

Doordat de bemesting uitsluitend uit kunstmest bestaat, is de aanvoer van EOS beperkt en waarschijnlijk onvoldoende om de afbraak van bodem organische stof te kunnen compenseren en het bodem organisch stof gehalte in stand te houden. Mogelijk verklaart het ontbreken van een organische bemesting de relatief lage potentieel mineraliseerbare $\mathrm{N}$.

Op een aantal bodemindicatoren scoren de systemen vergelijkbaar, zoals de HWC, bulkdichtheid en indringingsweerstand. De indringingsweerstand in de laag $30-40 \mathrm{~cm}$ zoals opgenomen in de indicatorset is voor BASIS te diep, op deze diepte zit een zandlaag. Door het opnemen van de indringingsweerstand in de laag $15-30 \mathrm{~cm}$ komen mogelijke verschillen tussen de grondbewerkingen beter tot uiting.

Gezien de focus van de proef zijn een aantal aspecten van het management constant gehouden voor beide systemen (zoals beregening, gebruik van gewasbeschermingsmiddelen en zaai- en 
oogsttijdstippen), waardoor deze systeemprestaties gelijk zijn en verschil in eigenschappen niet tot uiting komen (bijvoorbeeld in de vochtvoorziening of weerbaarheid van het gewas).

Tabel 4-3 Systeemprestaties van de systemen 'Ploegen' en 'NKG+' in de systeemproef BASIS.

\begin{tabular}{|c|c|c|c|c|c|c|c|}
\hline $\mathrm{nr}$. & Indicator & Eenheid & $\begin{array}{l}\text { Doelgerichte } \\
\text { streefwaarde }\end{array}$ & $\begin{array}{l}\text { Goede } \\
\text { landbouwpraktijk }\end{array}$ & $\begin{array}{l}\text { Regionaal } \\
\text { gemiddelde }\end{array}$ & Ploegen & NKG+ \\
\hline 1 & Opbrengst & $\%$ & 100 & 75 & 70 & 70 & 67 \\
\hline 2 & Kwaliteit van product & $\%$ & 100 & 95 & 95 & 100 & 100 \\
\hline 3 & Saldo & & & & & & \\
\hline 4 & Stikstofoverschot & kg N/ha & 60 & 90 & 117 & -8 & -6 \\
\hline 5 & Fosfaatoverschot & kg P2O5/ha & 0 & 10 & 13 & 7 & 8 \\
\hline 7 & Fosfaatstatus & pw-getal & 25 & 25 & 70 & 22 & 23 \\
\hline 8 & Kalistatus & K-getal & & $14-18$ & & 17 & 19 \\
\hline 9 & EOS aanvoer & $\mathrm{kg} \mathrm{EOS/ha}$ & 2030 & 2000 & 1910 & 1730 & 1730 \\
\hline 10 & OS\% & $\%$ & $>2,76-3,62$ & 2,9 & $1,6-3,6$ & 2,9 & 2,9 \\
\hline 14 & PMN & $\mathrm{mg} / \mathrm{kg}$ & & $60-80$ & & 43 & 43 \\
\hline 17 & Bodembedekking & $\%$ & 100 & & & 56 & 76 \\
\hline 18 & Gewasbescherming & kg a.s./ha & & 6,5 & 8,5 & 6,5 & 6,5 \\
\hline 19 & Nmin najaar & $\mathrm{kg} \mathrm{N} / \mathrm{ha}$ & & 79,2 & & 31 & 31 \\
\hline 21 & Beregening & $\mathrm{mm} /$ ton & 0 & & & $\mathbf{0}$ & 0,1 \\
\hline 24 & Diesel & & & & & & \\
\hline 25 & Organische- $\mathrm{N}$ & $\%$ & 100 & & 46 & $\mathbf{0}$ & $\mathbf{0}$ \\
\hline 26 & Organische-P2O5 & $\%$ & 100 & & 84 & $\mathbf{0}$ & $\mathbf{0}$ \\
\hline
\end{tabular}

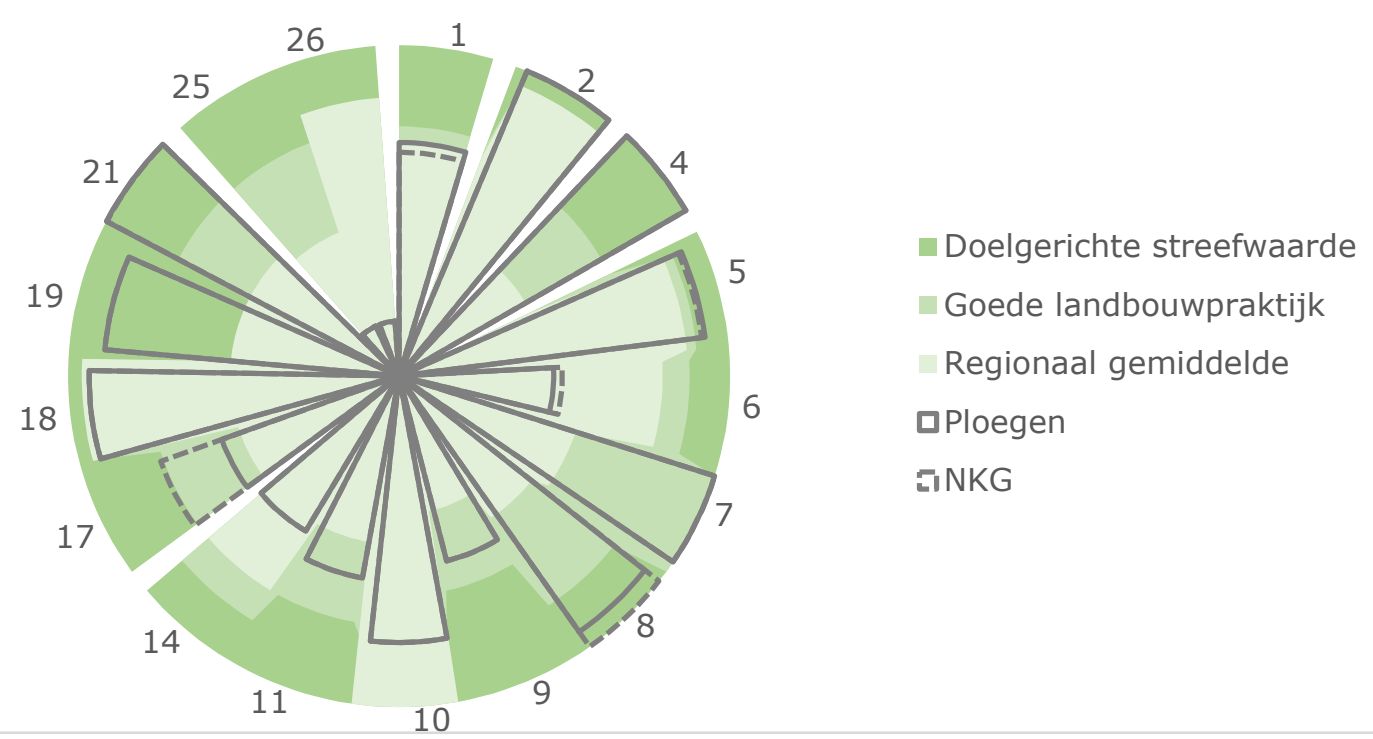

Figuur 4-3 BASIS: visuele weergave van de systeemprestaties van de opbrengst (1), kwaliteit (2), stikstofoverschot (4), fosfaatoverschot (5), stikstofstatus (6), fosfaatstatus (7), kalistatus (8), EOSaanvoer (9), OS\% (10), HWC (11), PMN (14), bodembedekking (17), gewasbeschermingsmiddelen (18), Nmin najaar (19), beregening (21), aandeel organische stikstof (25) en aandeel organische fosfaat (26). 


\section{$5 \quad$ Discussie en conclusie}

\section{$5.1 \quad$ Discussie}

\subsubsection{Indicatoren}

Aantal indicatoren en verdeling over thema's

De totale indicatorset is nog vrij groot. De selectie van indicatoren is arbitrair en gedaan op basis van dekking van alle ecosysteemdiensten in combinatie met de beschikbaarheid van gemakkelijk te meten indicatoren en beschikbaarheid data. Hierdoor zijn mogelijk te veel makkelijk te bepalen indicatoren opgenomen en te weinig indicatoren die lastig te meten zijn of waar de data van ontbreken. Er zijn bijvoorbeeld veel indicatoren geselecteerd rond bodemvruchtbaarheid en bemesting (8 van de 21 indicatoren). Enkele ecosysteemdiensten blijven onderbelicht, zoals plaagbeheersing en bestuiving (4), het bieden van habitat voor biodiversiteit (10), het bieden van recreatiewaarde en -mogelijkheden (11) en het bieden van sociale diensten (12). Hiervoor zijn lastig indicatoren af te leiden. Daarnaast ontbraken in bovenstaande voorbeelden voor enkele indicatoren de data: dit gold voor saldo en dieselverbruik. Deze studie biedt hiermee inzicht in de ecosysteemdiensten waar nieuwe indicatoren voor ontwikkeld moeten worden en indicatoren waar gerichter data voor verzameld moeten worden.

\section{Bodembiologie}

Bodembiologie is beperkt meegenomen in de huidige set aan indicatoren, de aanwezigheid of de activiteit van het bodemleven komt beperkt tot uiting in de HWC en PMN. Voor de samenstelling van de bodembiologie en de bodemweerbaarheid zijn geen specifieke indicatoren opgenomen. Ook voor de bodemgebonden ziekten en plagen is vooralsnog geen indicator opgenomen, al komen negatieve effecten hiervan wel tot uiting in de hoeveelheid en kwaliteit van de productie. Bodembiologische aspecten verdienen beslist meer aandacht om tot een goede integrale analyse te komen.

\section{Ontwikkeling van nieuwe indicatoren}

Op een aantal gebieden veranderen indicatoren in de komende tijd. Zo worden de bemestingsadviezen voor fosfaat en kali in de akkerbouw en groententeelt momenteel bijgesteld op basis van nieuwe indicatoren. Het is dan ook logisch om deze indicatoren hieraan te passen. In de BLN, versie 1.1 is hierop al ingespeeld (de Haan et al., 2021). Gebruik van gewasbeschermingsmiddelen uitgedrukt in kilogram actieve stof per hectare geeft geen inzicht in de totale belasting van het milieu. Momenteel is een nieuwe indicator in ontwikkeling, de 'Milieu-indicator Gewasbescherming'. Als deze beschikbaar is kan het de indicator gebruik van gewasbeschermingsmiddelen vervangen. Daarnaast is het gebruik van gewasbeschermingsmiddelen geen directe maatstaf voor de ziekte- en plaagdruk of de weerbaarheid van het systeem. Het is gewenst om hier een aparte indicator voor op te nemen.

\subsubsection{Streefwaarden en referentiewaarden}

Doelgerichte streefwaarden, goede landbouwpraktijk en regionale gemiddeldes Streefwaardes zijn opgesteld voor diverse ambitieniveaus omdat de systeemproeven niet zijn gericht op een algehele totale systeemoptimalisatie. De ambitie is echter wel om over het gehele systeem op het niveau van goede landbouwpraktijk te functioneren en tenminste zo goed als het regionale gemiddelde (referentiewaarde). Op de specifieke doelen van de proef is het doel om de doelgerichte streefwaardes te behalen. Echter voor een veel indicatoren ontbreken de streefwaarden en referentiewaarden en moeten deze dus nog gedefinieerd worden. Vraag is of onderscheid tussen goede landbouwpraktijk en doelgerichte streefwaarde nodig is mede omdat goede landbouwpraktijk ook inhoud dat rekening wordt gehouden met maatschappelijke doelstellingen.

\section{Streefwaarden gewasopbrengst}

De streefwaarden voor de gewasopbrengsten kennen verschillende bronnen, een uniforme is aanpak gewenst. Als regionaal gemiddelde kunnen de Agrimatie opbrengsten goed gebruikt worden. Echter deze zijn niet voor alle gewassen beschikbaar. De gewasopbrengsten uit de KWIN kunnen gebruikt worden als goede landbouwpraktijk. Echter aanscherping van deze opbrengstniveaus is soms nodig aan specifieke omstandigheden. Dit kan in overleg met de leden van de begeleidingscommissie van de proeven gebeuren. In de KWIN gaat het om meerjarige gemiddelde opbrengsten. Als de opbrengst van 
1 jaar vergeleken wordt moet rekening gehouden worden met de jaarvariatie. Voor een aantal gewassen zou ook gewerkt kunnen worden met de potentiële en/of watergelimiteerde opbrengsten uit modelberekeningen, eventueel aangepast met een correctiefactor voor praktijkomstandigheden.

\section{Nutriëntenoverschotten}

De methodiek voor het berekenen van het stikstof- en fosfaatoverschot blijkt niet bruikbaar voor systemen waarbij relatief veel organische mest met een laag (eerstejaars) stikstofwerkingspercentage werd aangevoerd. Door de veronderstelde evenwichtssituatie wordt de totale stikstof in organische mest meegenomen als aanvoer, waardoor het stikstofoverschot erg hoog is en grote nutriëntenverliezen impliceert. Deze evenwichtssituatie blijkt in de praktijk er nog niet te zijn, ondanks dat proeven al 10 jaar of meer lopen. Uit de studie van de Haan et al. (2018) is echter gebleken dat de aanvoer van extra stikstof in compost geen verhoogd risico geeft op nitraatuitspoeling. Om tot een betere berekening van het stikstofbodemoverschot te komen, dient de aanvoer uit organische mest gecorrigeerd te worden naar de aanvoer van (eerstejaars) werkzame stof en dient er een mineralisatiecomponent opgenomen te worden voor toegediende organische mest in eerdere jaren.

Streefwarden voor gangbare en biologische landbouw

Vooralsnog is de set aan indicatoren getoetst op gangbare systemen. Voor biologische systemen gelden mogelijk andere doelen (bijvoorbeeld met betrekking tot de goede landbouwpraktijk) en dienen streefwaarden aangepast te worden.

\subsubsection{Berekening en presentatie systeemprestaties}

\section{Normalisatie}

Om de indicatoren onderling in een figuur te vergelijken is een normalisatie nodig. Hierbij wordt de doelgerichte streefwaarde op $100 \%$ gesteld en wordt de afwijking hiervan berekend, zowel voor de goede landbouwpraktijk als de regionale referentiewaarden. Uit de figuren worden verschillen duidelijk tussen deze niveaus. Dit is goed verklaarbaar uit de verschillende achtergronden van de verschillende streefwaarden tussen indicatoren en ook per indicatoren maar ook lastig in de interpretatie zowel inhoudelijk als in de visualisatie.

\section{Presentatie gegevens}

De tabellen met de systeemprestaties geven een duidelijk overzicht van de prestaties maar het is lastig om de prestaties tussen indicatoren onderling goed te vergelijken. In de figuur wordt dit beter zichtbaar al is de figuur complex vanwege de combinatie van verschillende ambities in streefwaarde en de prestaties van de twee beschouwde systemen per proef. Dit heeft ook te maken met verschil in de relatieve verschillen tussen realisatie in de praktijk, de goede landbouwpraktijk en doelgerichte streefwaarde tussen de indicatoren. Voor een duidelijke visualisatie zouden die vergelijkbaar moeten zijn. Daarnaast zijn voor veel indicatoren (beter onderbouwde) streefwaarden nodig.

Bovendien zijn de indicatoren niet gelijk verdeeld over de verschillende ecosysteemdiensten. Hierdoor worden de ecosysteemdiensten met veel indicatoren extra benadrukt en komen andere ecosysteemdiensten zonder indicatoren niet en ecosysteemdiensten met een indicator nauwelijks naar voren. Een presentatie als in Wijnands en Dekking (2002) of Tonneijck en de Haan (2006) zorgt dat alle thema's of ecosysteemdiensten eenzelfde oppervlak hebben (zie bijlage 1 ).

\section{Gewicht van gewassen in berekening systeemprestatie}

De opbrengsten van alle gewassen tellen elk even zwaar in de systeemprestatie, hierin zou onderscheid gemaakt kunnen worden door belangrijke gewassen in de rotatie een zwaardere wegingsfactor te geven. Echter, de opbrengsten van waardevolle gewassen komen wel tot uitdrukking in het saldo, wanneer deze berekend is de noodzaak om wegingsfactoren aan gewassen toe te kennen beperkt.

\subsubsection{Eindresultaat}

Het doel van het in beeld brengen van de systeemprestaties van systeemproeven is om te bezien op welke onderdelen wijzigingen van het systeem nodig zijn. Dit kunnen zowel operationele wijzigingen zijn (bijv. de uitvoering van gewasbescherming in gewas $X$ moet anders) als strategische wijzigingen (in de zin van bijvoorbeeld bouwplan of algehele bemestingsstrategie). Over de volle breedte wordt daarbij in het systeem gestreefd naar ten minste goede landbouwpraktijk en op onderdelen naar de doelgerichte streefwaarde. De drie voorbeelden maken zichtbaar dat voor een aantal indicatoren dit streven nog niet bereikt wordt. Dit betekent niet dat de systemen nu grondig aangepakt dienen te worden omdat: 
- De beoordeling gebaseerd is op 1 jaar (2019). Het is van belang ook naar andere jaren te kijken.

- De kwaliteit van de streefwaardes soms niet goed is of hier met grote aannames gerekend is.

- De normalisatiestappen goed bekeken moeten worden in hoeverre er daadwerkelijk (grote) afwijking is van de beoogde streefwaarde.

- Voor een klein deel van indicatoren de afwijking bewust kan zijn (bijvoorbeeld toediening van compost met een hoge additionele aanvoer van stikstof en fosfaat en daarmee een hoog overschot).

Dit betekent dat voor een algemeen gebruik de systematiek verder verbeterd moet worden.

\subsection{Conclusies}

Een nieuwe indicatorset voor het beoordelen van systeemproeven is opgesteld. Deze indicatorset beslaat zo goed mogelijk de ecosysteemdiensten die in de open teelten vervuld dienen te worden. Het blijkt echter lastig om voor alle ecosysteemdiensten ook eenvoudig meetbare indicatoren te definiëren en dan ook de data voor het bepalen van deze indicatoren te verzamelen. Ook ontbreekt voor een deel van de indicatoren nog een bruikbare streefwaarde op de verschillende ambitieniveaus en moet verder gewerkt worden aan de normalisatie en visualisatie van de resultaten. Niettemin geeft de indicatorset een eerste beeld van de systeembrede prestaties van de onderzochte systemen in de systeemproeven en daarmee handvatten waarmee de systemen ook breder dan alleen de specifieke doelen in het systeemonderzoek verbeterd kunnen worden.

\subsection{Aanbevelingen}

De volgende aanbevelingen kunnen vanuit deze studie gedaan worden:

- Indicatorset

- Het belang van alle indicatoren (nogmaals) nagaan.

- Het opnemen van indicatoren zodat alle ecosysteemdiensten in dezelfde mate vertegenwoordigd zijn.

- Streefwaarden

- Zoeken naar en vaststellen van ontbrekende streefwaarden en beter onderbouwen van slecht onderbouwde streefwaarden.

- Normalisatie en presentatie verbeteren

- Presentatie door ecosysteemdiensten gelijke oppervlakten te geven in de diagrammen.

- Afstemmen van indicatorset, streefwaarden, normalisatie en presentatie met stakeholders.

- Systeemproeven

- Het doorrekenen van indicatoren die vooralsnog ontbreken, zoals saldo, energieverbruik en de milieu-indicator gewasbescherming.

- Het doorrekenen van een reeks aan meetjaren.

- Vaststellen van tekorten en opstellen van mogelijke verbeterplannen voor de systemen. 


\section{Literatuur}

Agrimatie (2021-a). Stikstofbodemoverschot per ha - Akkerbouw [Dataset]. Beschikbaar via: https://www.agrimatie.nl/

Agrimatie (2021-b). Fosfaatbodemoverschot per ha - Akkerbouw [Dataset]. Beschikbaar via: https://www.agrimatie.nl/

Agrimatie (2021-c). Stikstofbemesting per ha - Akkerbouw [Dataset]. Beschikbaar via: https://www.agrimatie.nl/

Agrimatie (2021-d). Fosfaatbemesting per ha - Akkerbouw [Dataset]. Beschikbaar via: https://www.agrimatie.nl/

Avebe (2020). Verslag Avebe-agro teeltoptimalisatie optimeel oogstjaar 2019. Beschikbaar via: https://demo.avebe.com/wp-content/uploads/Optimeelverslag-teeltjaar-2019-NL.pdf

van Bavel, J. (2011). Focus op veredeling, teelt en vermarkting van erwten. Landbouw \& Techniek. Beschikbaar via: https://edepot.wur.nl/301865

Buck, A.J. de, F.J. de Ruijter, F. Wijnands, P.L.A. van Enckevort, W. van Dijk, A.A. Pronk, J. de Haan \& R. Booij (2000). Voorwaarts met de milieuprestaties van de Nederlandse open-teelt sectoren: een verkenning naar 2020. Wageningen : Plant Research International, (Rapport / Plant Research International 6) - p. 138.

Bus, C.B. (2002). Onderzoek bestrijding gewone schurft in aardappel. Praktijkonderzoek Plant \& Omgeving. Beschikbaar via: https://edepot.wur.nl/120266

Conijn, J.G. and Lesschen, J.P. (2015). Soil organic matter in the Netherlands: quantification of stocks and flows in the top soil. Wageningen University and Research, nr. 619. Beschikbaar via:

https://edepot.wur.nl/375943

de Haan, J.J., Rombout, S., Molendijk, L.P.G., Thoden, T., Hoek, H., de Wolf, P.L. en Sukkel, W. (2019). Meten is Weten anno 2015. Ontwikkeling van de WUR Minimale Data Set tot 2015 voor het meten van de bodemkwaliteit in de open teelten als basis voor verdere ontwikkeling. Wageningen Research, Rapport WPR-821. doi: 10.18174/511394

de Haan, J.J., van Asperen, P., Visser, J., van der Burgert, G.J., Smit, E., Dawson, A. en Klompe, K. (2020). Bodemmaatregelen op dalgrond in de Veenkoloniën: effecten op bodemkwaliteit, opbrengst en financiële meerwaarde. Analyse van de resultaten van de systeemproef Bodemkwaliteit Veenkoloniën 2014-2017. Wageningen Research, Rapport WPR-831. doi: 10.18174/520429

de Haan, J.J., Wesselink, M., van Dijk, W., Verstegen, H.A.G., van Geel, W.C.A., van den Berg, W. (2017). Effect van organische stofbeheer op opbrengst, bodemkwaliteit en stikstofverliezen op een zuidelijke zandgrond. Resultaten van de gangbare bedrijfssystemen van het project Bodemkwaliteit op zand in de periode 2011-2016. Wageningen Research, Rapport WPR-754.

de Haan, J.J. de, Garzia Diaz, A. (2002) Manual on prototyping methodology and multifunctional crop rotation, Vegineco, Applied Plant Research BV, Lelystad. Beschikbaar via: https://edepot.wur.nl/11786

de Haan, J.J., van den Elsen, E. en Visser, S.M. (2021). Evaluatie van de Bodemindicatoren voor Landbouwgronden in Nederland (BLN), versie 1.0. Wageningen University and research, Rapport WPR883. doi: $10.18174 / 549973$ 
Handboek Bodem en Bemesting [HBB] (n.d.). Bodemgericht advies. Beschikbaar via: https://www.handboekbodemenbemesting. nl/nl/handboekbodemenbemesting/Handeling/Bemesting.ht $\mathrm{m}$

Erisman, J.W. en Verhoeven, F. (2020). Integraal op weg naar kringlooplandbouw 2030 - Een voorstel voor kritische prestatie indicatoren systematiek. Louis Bolk Instituut, Rapport 2020-010LbP.

van den Elsen, E., van Tol-Leenders, D., Teuling, K., Römkens, P, de Haan, J., Korthals, G. en Reijneveld, A. (2020). De staat van de Nederlandse landbouwbodems in 2018; Op basis van beschikbare landsdekkende dataset (CC-NL) en bodem-indocatorenlijst (BLN). Wageningen Environmental Research, Rapport 3048. doi: 10.18174/537281

Ghani, A., Dexter, M. en Perrott, K.W. (2003). Hot-water extractable carbon in soils: a sensitive measurement for determining impacts of fertilisation, grazing and cultivation. Soil Biology and Biochemistry, 35(9), 1231-1243.

Hanegraaf, M., van den Elsen, E., de Haan, J., \& Visser, S. (2019). Bodemkwaliteitsbeoordeling van landbouwgronden in Nederland-indicatorset en systematiek, versie 1.0 (No. 795).

Hoving, I. (2005). N-mineraal in bodem indicator voor nitraat in grondwater. Beschikbaar via: https://edepot.wur.nl/113556

Koopmans, C.J., Erisman, J.W., Zanen, M., Luske, B. (2017). Biodiverse akkerbouw, verkenning van indicatoren voor agrobiodiversiteit in de akkerbouw. Louis Bolk Instituut, nr. 2017-023 LbP.

Beschikbaar via: https://edepot.wur.nl/428546

de Kraker, J. (n.d.). Verbetering van de kwaliteit van winterprei. Beschikbaar via:

https://edepot.wur.nl/332920

Lukács, S., Blokland, P.W., Prins, H., Vrijhoef, A., Fraters, D., en Daatselaar, C.H.G. (2019). Landbouwpraktijk en waterkwaliteit op landbouwbedrijven aangemeld voor derogatie in 2017. RIVM, rapport 2019-0025. doi: 10.21945/RIVM-2019-0025

Meuffels, G. en Kronen, M. (2017). Onderzoek geïntegreerde bestrijding wortelvlieg (Psila rosae). Praktijkonderzoek Plant \& Omgeving, nr. 3750340800.

Molendijk, L.P.G., de Wolf, P.L. en Wesselink, M. (2018). Instrumenten voor Duurzaam Bodembeheer. Wageningen Research, Rapport WPR-740. doi: 10.18174/455058

Noij, G.J., Schnabel, S., en ten Berge, H. (2021). Addendum, horende bij Noij, C.J. en ten Berge, H. (2019). Rapportage Project Nitraatwijzer Fase I. Wageningen Research, Rapport WPR-917.

Queisen, G. (2019). 16,3 Procent in 2019: laagste suikerpercentage in tien jaar. Akkerwijzer. Beschikbaar via: https://www.akkerwijzer.nl/artikel/233739-16-3-procent-in-2019-laagstesuikerpercentage-in-tien-jaar/

Reubens, B., Ruysschaert, G., D'Hose, T., D'Haene, K. (2012). Bodembreed: overzicht van resultaten, inzichten en aanbevelingen. Instituut voor Landbouw- en Visserijonderzoek. Beschikbaar via: http://www.bodembreed.eu/resultaten

Rutgers, M., Mulders, C., Schouten, A.J., Bloem, J., Bogte, J.J., Breure, A.M., Brussaard, L., de Goede, R.G.M., Faber, J.H., Jagers op Akkerhuis, G.A.J.M., Keidel, H., Korthals, G.W., Smeding, F.W., ter Berg, C., en van Eekeren, N. (2007). Typeringen van bodemecosystemen in Nederland met tien referenties voor biologische bodemkwaliteit. RIVM, nr. M/607604. Beschikbaar via:

https://edepot.wur.nl/40979 
Schils, R.L.M. (2012). 30 vragen en antwoorden over bodemvruchtbaarheid. Wageningen University and Research. Beschikbaar via: https://edepot.wur.nl/211205

da Silva, J. V., Reidsma, P., en van Ittersum, M. K. (2017). Yield gaps in Dutch arable farming systems: Analysis at crop and crop rotation level. Agricultural Systems, 158, 78-92.

Sukkel, W. en Rovers. J.A.J.M. (2002). Geïntegreerde akkerbouw / vollegrondsgroenteteelt, Zuidwest Nederland. Praktijkonderzoek Plant \& Omgeving, 306-5.

Sukkel, W. en Koot, P.A.C. (2002). Biologische vollegrondsgroenteteelt, Zuidoost Nederland. Praktijkonderzoek Plant \& Omgeving, 306-6.

Sukkel, W. en Koot, P.A.C. (2002). Geïntegreerde vollegrondsgroenteteelt, Zuidoost Nederland. Praktijkonderzoek Plant \& Omgeving, 306-7.

Sukkel, W. en Rovers. J.A.J.M. (2002). Biologische akkerbouw / vollegrondsgroenteteelt, Zuidwest Nederland. Praktijkonderzoek Plant \& Omgeving, 306-8.

Timmer, R.D., Jansen, H., Staal, J., Nijenhuis, C.M.A., en van Bon, K.B. (1989). Teelt van droge erwten. Proefstation en Consulentschap in Algemene dienst voor de Akkerbouw en de Groenteteelt in de Vollegrond. Beschikbaar via: https://edepot.wur.nl/254841

Tol-Leenders, D., Knotters, M., de Groot, W., Gerritsen, P., Reijneveld, A., van Egmond, F. Wösten, H. en Kuikman, P. (2019). Koolstofvoorraad in de bodem van Nederland (1993-2018): CC-NL. Wageningen University and Research, nr. 2971. doi: 10.18174/509781

Tonneijck, A.E.G. \& J.J. de Haan (2006). Een instrument om de duurzaamheid van de biologische landbouw te meten. Rapport 123. Plant Research International. Wageningen.

Wijnands F.G., P. van Asperen, P.L. de Wolf \& J.J. de Haan (2003). Geïntegreerde Gewasbescherming; Ontwerpen testen en verbeteren. PPO-Bedrijfssystemen. Praktijkonderzoek Plant \& Omgeving. Lelystad.

Wijnands, F.G. en Dekking, A.J.G. (2002). Biologische akkerbouw, Centrale zeeklei. Praktijkonderzoek Plant \& Omgeving, 306-1.

Wijnands, F.G. en Kroonen-Backbier, B.M.A. (2002). Biologische akkerbouw, Zuidoost Nederland. Praktijkonderzoek Plant \& Omgeving, 306-2.

Wijnands, F.G. en van Asperen, P. (2002). Biologische akkerbouw, Noordoost Nederland. Praktijkonderzoek Plant \& Omgeving, 306-3.

Wijnands, F.G. en Dekking, A.J.G. (2002). Geïntegreerde akkerbouw, Centrale zeeklei. Praktijkonderzoek Plant \& Omgeving, 306-4.

Wijnands, F.G. en van Asperen, P. (2002). Geïntegreerde akkerbouw, Noordoost Nederland. Praktijkonderzoek Plant \& Omgeving, 306-9.

Wijnands, F.G. en Kroonen-Backbier, B.M.A. (2002). Geïntegreerde akkerbouw, Zuidoost Nederland. Praktijkonderzoek Plant \& Omgeving, 306-10.

Veerman, A. (2003). Teelt van consumptieaardappelen. Praktijkonderzoek Plant \& Omgeving.

Zanen, M., Bokhorst, J.G., ter Berg, C. en Koopmans, J.C. (2008). Investeren tot in de bodem, evaluatie van het proefveld Mest als Kans. Louis Bolk Instituut, rapport LD11. 


\section{Bijlage 1 Presentatie systeemprestaties}

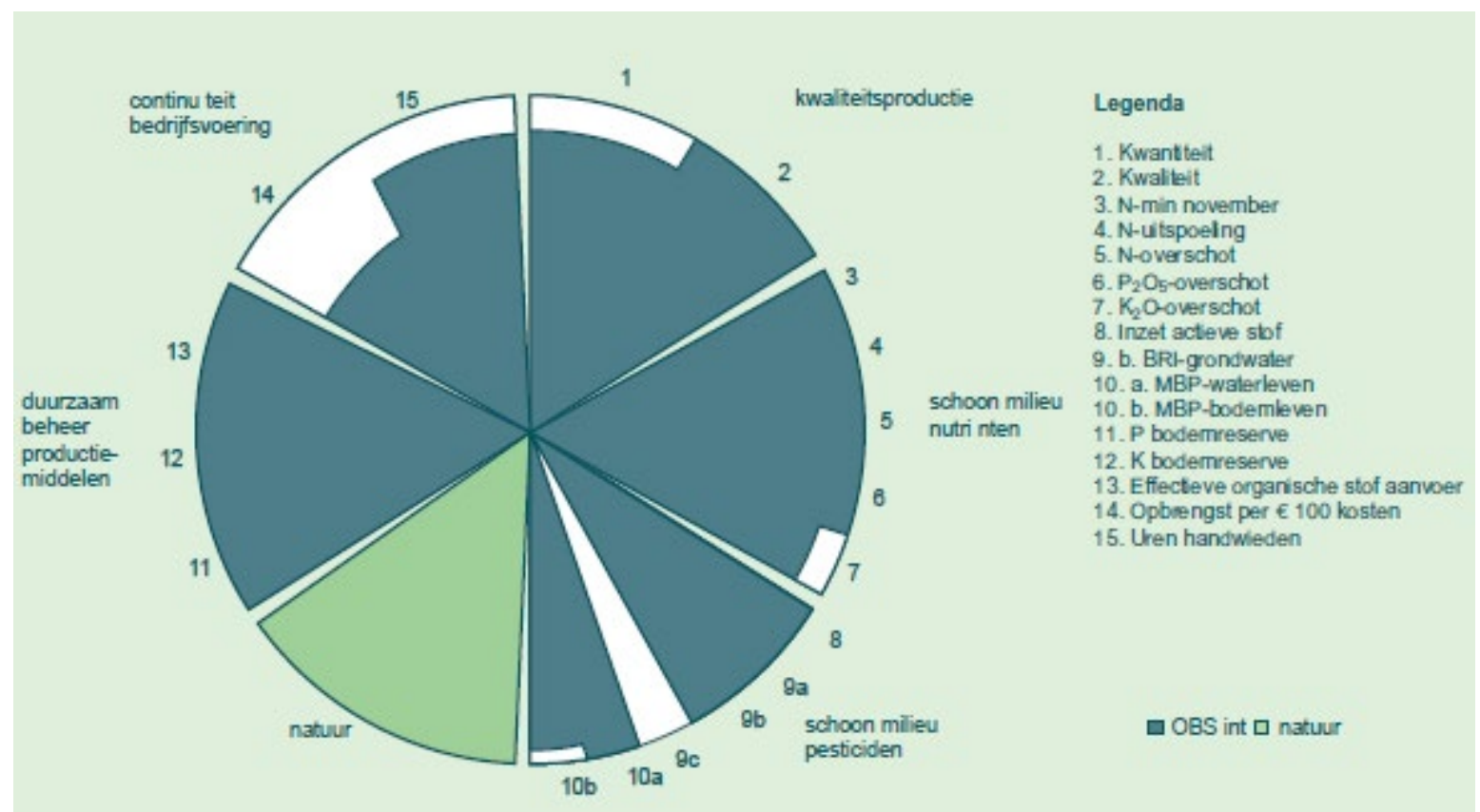

Figuur 5-1 Weergave van de resultaten van het geïntegreerde bedrijfssysteem ten opzichte van de streefwaarden, uit Wijnands en Dekking (2002).

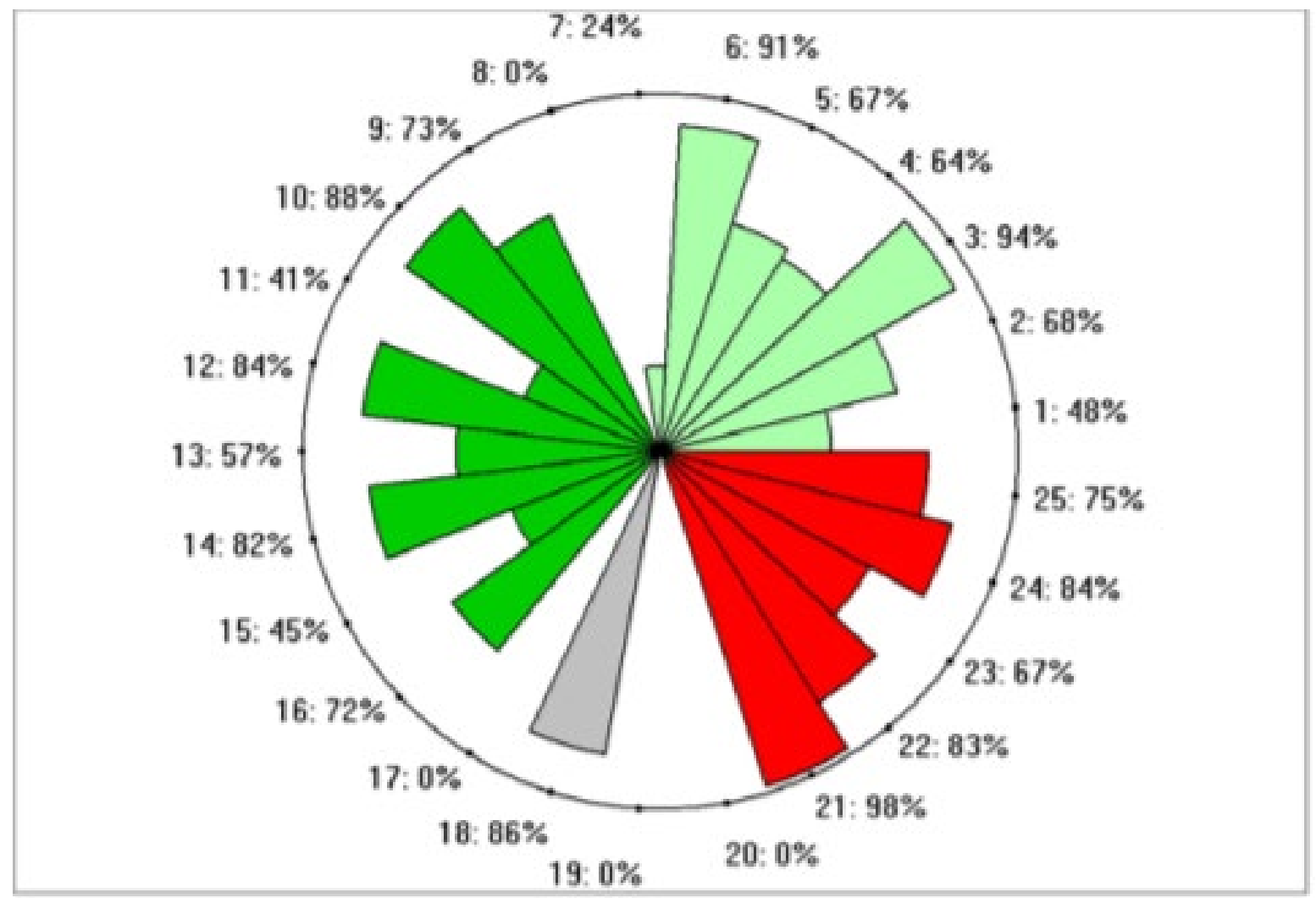

Figuur 5-2 Weergave van de prestaties op verschillende indicatoren van akkerbouw op klei in vergelijking tot de referentiewaarden, uit Rutgers et al. (2007). 


\section{Dimensie Profit}

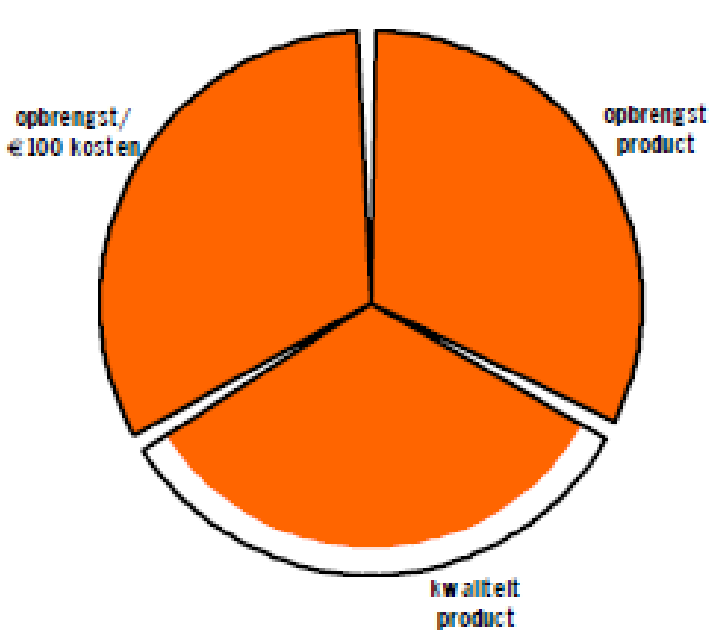

\section{Dimensie People}

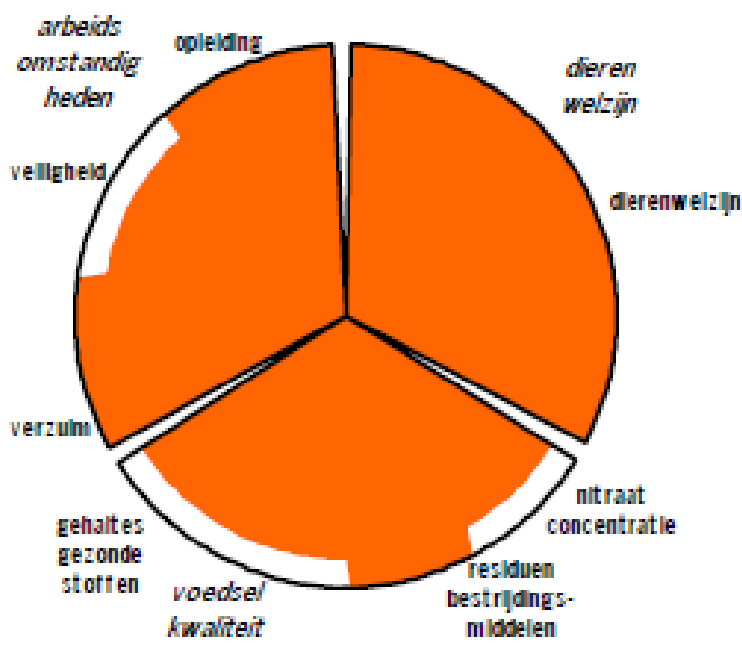

Dimensie Planet

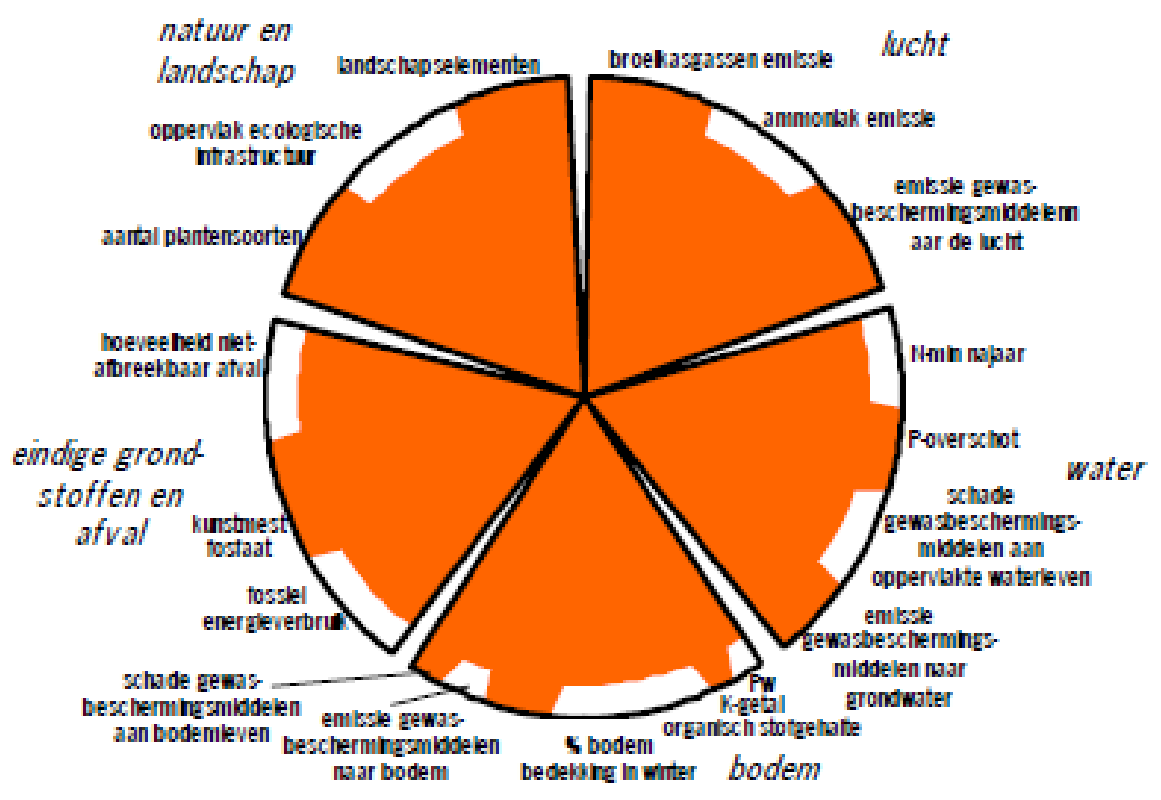

Figuur 5-3 Cirkeldiagrammen per dimensie met thema's en indicatoren, uit Tonneijck en de Haan (2006). 


\section{Bijlage 2 Long-list indicatoren}

Tabel 5-1 Long-list aan mogelijke systeemindicatoren

\section{Hoofdindeling systeemeigenschap}

Bodemkwaliteit en gewas Bodemkwaliteit en gewas Bodemkwaliteit en gewas Bodemkwaliteit en gewas Bodemkwaliteit en gewas

Bodemkwaliteit en gewas

Bodemkwaliteit en gewas Bodemkwaliteit en gewas Bodemkwaliteit en gewas Bodemkwaliteit en gewas

Bodemkwaliteit en gewas Bodemkwaliteit en gewas Bodemkwaliteit en gewas Bodemkwaliteit en gewas Bodemkwaliteit en gewas Bodemkwaliteit en gewas Bodemkwaliteit en gewas Bodemkwaliteit en gewas Bodemkwaliteit en gewas Bodemkwaliteit en gewas Bodemkwaliteit en gewas Circulariteit en grondstoffen Circulariteit en grondstoffen Circulariteit en grondstoffen Circulariteit en grondstoffen Circulariteit en grondstoffen Circulariteit en grondstoffen Circulariteit en grondstoffen Circulariteit en grondstoffen Circulariteit en grondstoffen Circulariteit en grondstoffen Circulariteit en grondstoffen Circulariteit en grondstoffen Circulariteit en grondstoffen

Circulariteit en grondstoffen Emissies en leefomgeving

Emissies en leefomgeving Emissies en leefomgeving

Emissies en leefomgeving Emissies en leefomgeving Emissies en leefomgeving Emissies en leefomgeving Emissies en leefomgeving Emissies en leefomgeving Emissies en leefomgeving Emissies en leefomgeving

\section{Indicator}

Stikstofoverschot

Fosfaatoverschot

Stikstofstofstatus

$\mathrm{K}$-overschot

Fosfaatstatus

Kalistatus

Organische stof balans

Organische stof gehalte

Labiele koolstoffractie (HWC)

Indringingsweerstand $30-40 \mathrm{~cm}$, max

0-50 cm, evt 0-10 cm

Droge bulkdichtheid $30-40 \mathrm{~cm}$

Biomassa micro-organismen

Zuurgraad $\mathrm{pH}$

Regenwormen aantal en diversiteit

Stabiele fractie organisch stof (POXC)

Ziekte per gewas

Aggregaatstabiliteit

Plagen per gewas

Watervasthoudend vermogen

Nematoden aantallen en diversiteit

Bacterie- en schimmelbiomassa

Koolstofopslag in bodem

Waterverbruik

Directe energiegebruik

Hernieuwbare energie geproduceerd

Diesel verbruik

Stikstof-zelfvoorziening

Gebruik kunstmest N

Verbruik fosfaatkunstmest

Aandeel meststoffen uit reststromen

Verhouding type landgebruik

Voedselverspilling

Aandeel voeder uit de regio

Andeel voeder ingrediënten ook

geschikt voor humane consumptie

Uitstoot van broeikasgassen

Aandeel natuurelementen op gronden in $\%$

beheer

Gemiddelde perceelsbreedte

Percentage bodembedekking in de

winter

Gebruik gewasbeschermingsmiddelen

Waterkwaliteit

BRI-lucht

BRI-grondwater

BRI-bodem

MBP-waterleven

MPB-bodemleven

Percentage kruidenrijk grasland
Eenheid

$\mathrm{kg} / \mathrm{ha}(0-100 \mathrm{~cm})$

$\mathrm{kg}$ P2O5 per ha

$\mathrm{kg} \mathrm{N} / \mathrm{ha}$

$\mathrm{kg} \mathrm{K} 2 \mathrm{O} / \mathrm{ha}$

$\mathrm{mg} \mathrm{P} 205 / 100 \mathrm{~g}, \mathrm{~kg} / \mathrm{ha}$, $\mathrm{mg} / 100 \mathrm{ml}, \mathrm{kg} / \mathrm{ha}$

$\mathrm{mmol}+/ \mathrm{kg}, \mathrm{kg} / \mathrm{ha}, \mathrm{mg} / 100$

$g$

kg EOS per ha

$\%$

$\mu \mathrm{g} \mathrm{C} / \mathrm{g}$

$\mathrm{Pa} / \mathrm{cm} 2, \%$ gronden

verdicht,

$\%$ gronden verdicht

$\mathrm{mg} / \mathrm{kg}, \mathrm{g} / \mathrm{ha}$

Aantal $/ \mathrm{m} 2, \mathrm{~kg} / \mathrm{m} 2$

$\%$

$\%, \mathrm{~mm}$

$\mu \mathrm{g} / \mathrm{kg}$

t/ha

$\mathrm{m} 3 / \mathrm{t}$ product

Kilowatt

Kilowatt

L/ ton product

$\%$

$\mathrm{kg} / \mathrm{ha}$

$\mathrm{kg} / \mathrm{ha}$

$\%$

$\%$

$\%$

$\%$

kg CO2-eq./jaar

$\%$

m

$\%$

$\mathrm{kg}$ actieve stof/ha

$\mathrm{kg} \mathrm{N} / \mathrm{ha}$

-

$-$

$\%$ 
Emissies en leefomgeving

Klimaat en leefomgeving

Klimaat en leefomgeving

Klimaat en leefomgeving

Klimaat en leefomgeving

Klimaat en leefomgeving

Klimaat en leefomgeving

Sociaal-economisch

Sociaal-economisch

Sociaal-economisch

Sociaal-economisch

Sociaal-economisch

Sociaal-economisch

Sociaal-economisch

Sociaal-economisch

Sociaal-economisch
Percentage blijvend grasland

Bodemkruipende insecten

Flora diversiteit

Vogelindex

Broeikasgassenemissie

Ammoniakemissie

Waterkwaliteit

Opbrengst

Kwaliteit van product

Saldo

Training/opleiding

Aantal netwerken

Arbeidsefficiëntie

Arbeidsongevallen

Machinepark

Ziekte en verzuim
$\%$

Aantal/m2

kg CO2-eq./jaar

$\mathrm{kg} / \mathrm{jaar}$

$\mathrm{mg} \mathrm{NO3/I}$

$\%$

$€$

uren per jaar

Aantal

$\%$

Aantal

$€$

Dagen 


\section{Bijlage 3 Streefwaarden gewasopbrengst}

Tabel 5-2 Streefwaarden voor de gewasopbrengsten, uitgesplitst naar drie ambitieniveaus en drie grondsoorten.

\begin{tabular}{|c|c|c|c|c|c|c|c|c|c|c|c|c|c|}
\hline \multirow[b]{3}{*}{ Naam } & \multirow[b]{3}{*}{ Eenheid } & \multicolumn{3}{|c|}{ Ambitieniveau: hoog } & \multicolumn{3}{|c|}{ Ambitieniveau: middel } & \multicolumn{3}{|c|}{ Ambitieniveau: laag } & \multirow[t]{3}{*}{ Bron 1} & \multirow[t]{3}{*}{ Bron 2} & \multirow[t]{3}{*}{ Bron 3} \\
\hline & & \multicolumn{3}{|c|}{ Doelgerichte streefwaarde } & \multicolumn{3}{|c|}{ Beste landbouwpraktijk } & \multicolumn{3}{|c|}{ Regionaal gemiddelde } & & & \\
\hline & & Klei & Zand & Dalgrond & Klei & Zand & Dalgrond & Klei & Zand & Dalgrond & & & \\
\hline Opbrengst & & & & & & & & & & & & & \\
\hline $\begin{array}{l}\text { Consumptieaard } \\
\text { appel }\end{array}$ & ton/ha & 72,6 & 60 & & & 55 & & 53,4 & 47,1 & & \begin{tabular}{|l} 
da Silva et al. \\
(2017)
\end{tabular} & Beste $20 \%$ uit de regio & Agrimatie (2019) \\
\hline Erwt & ton/ha & 10 & 10 & & 7,5 & 7,5 & & 6,4 & 6,4 & & $\begin{array}{l}\text { Timmer et al. } \\
\text { (1998) }\end{array}$ & van Bavel (2011) & $\begin{array}{l}\text { Eigen data praktijkperceel } \\
\text { BKZ (2011-2019) }\end{array}$ \\
\hline Grasklaver & ton/ha & & & & & & & & & & & & \\
\hline Kool & ton/ha & & & & & & & 85,5 & 85,5 & & & & KWIN (2015) \\
\hline Lelie & ton/ha & & & & & & & 27 & 27 & & & & KWIN (2015) \\
\hline Peen & ton/ha & & 150 & & & 130 & & 87,5 & 68,8 & & $\begin{array}{l}\text { Eenmalige } \\
\text { praktijkopbrengst } \\
\text { (2017) }\end{array}$ & Beste $20 \%$ uit de regio & KWIN (2015) \\
\hline Pootaardappel & ton/ha & 55,5 & & & 37,9 & & & 37,5 & 29,7 & & $\begin{array}{l}\text { Timmer et al. } \\
(1998)\end{array}$ & Agrimatie (2019) & Agrimatie (2019) \\
\hline Prei & ton/ha & & 50 & & & 42,4 & & & 37 & & \begin{tabular}{|l|} 
Eigen data \\
praktijkperceel \\
BKZ
\end{tabular} & \begin{tabular}{|l} 
Eigen data praktijkperceel BKZ \\
B
\end{tabular} & $\begin{array}{l}\text { Eigen data praktijkperceel } \\
\text { BKZ }\end{array}$ \\
\hline Snijmais & ton/ha & & 57 & & & 51 & & & 46 & & $?$ & Beste $20 \%$ uit de regio & KWIN (2015) \\
\hline Suikerbiet & ton/ha & 107,1 & 107,1 & 107,1 & 90 & 90 & 90 & 90,5 & 73,5 & 73,5 & $\begin{array}{l}\text { da Silva et al. } \\
\text { (2017) }\end{array}$ & Streven Suikerunie & Agrimatie (2019) \\
\hline Tagetes & ton/ha & & & & & & & & & & & & \\
\hline $\mathrm{Ui}$ & ton/ha & 88,3 & 88,3 & & 55,7 & 55,7 & & 51,5 & 54,8 & & $\begin{array}{l}\text { da Silva et al. } \\
\text { (2017) }\end{array}$ & Agrimatie (2017) & Agrimatie (2019) \\
\hline Veldbonen & ton/ha & & & & & & & & & & & & \\
\hline $\begin{array}{l}\text { Zetmeelaardapp } \\
\text { el }\end{array}$ & ton/ha & & & 71,6 & & & 40,5 & & & 37,4 & $\begin{array}{l}\text { da Silva et al. } \\
\text { (2017) }\end{array}$ & Beste $20 \%$ uit de regio & KWIN (2015) \\
\hline Zomergerst & ton/ha & 10,4 & 10,4 & 10,4 & 9 & 7,2 & 7,2 & 7,7 & 6,1 & 6,1 & $\begin{array}{l}\text { da Silva et al. } \\
\text { (2017) }\end{array}$ & $\begin{array}{l}\text { Timmer (1999) en eigen data } \\
\text { praktijkperceel BKZ (2011-2019) }\end{array}$ & Agrimatie (2019) \\
\hline Zomertarwe & ton/ha & 11,6 & 11,6 & 11,6 & & & & 7,4 & 7,4 & & $\begin{array}{l}\text { Global Yield Gap } \\
\text { Atlas }\end{array}$ & Beste $20 \%$ uit de regio & KWIN (2015) \\
\hline
\end{tabular}




\section{Bijlage 4 Streefwaarden kwaliteit}

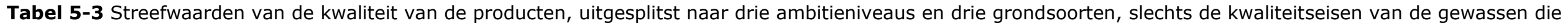
geteeld worden in de drie systeemproeven zijn in deze tabel opgenomen.

\begin{tabular}{|c|c|c|c|c|c|c|c|c|c|c|c|c|c|}
\hline \multirow[b]{3}{*}{ Naam } & \multirow[b]{3}{*}{ Eenheid } & \multicolumn{3}{|c|}{ Ambitieniveau: hoog } & \multicolumn{3}{|c|}{ Ambitieniveau: middel } & \multicolumn{3}{|c|}{ Ambitieniveau: laag } & \multirow[t]{3}{*}{ Bron hoog } & \multirow[t]{3}{*}{ Bron middel } & \multirow[t]{3}{*}{ Bron 3 laag } \\
\hline & & \multicolumn{3}{|c|}{ Doelgerichte streefwaarde } & \multicolumn{3}{|c|}{ Beste landbouwpraktijk } & \multicolumn{3}{|c|}{ Regionaal gemiddelde } & & & \\
\hline & & Klei & Zand & Dalgrond & Klei & Zand & Dalgrond & Klei & Zand & Dalgrond & & & \\
\hline Opbrengst & & & & & & & & & & & & & \\
\hline $\begin{array}{l}\text { Consumptieaard } \\
\text { appel }\end{array}$ & OWG (gram) & & $<450$ & & & 380 & & & 360 & & AGV (2003) & Schatting & $\begin{array}{l}\text { Eigen data praktijkperceel } \\
\text { BKZ (2019) }\end{array}$ \\
\hline Erwt & TM (index) & & 120 & & & 120 & & & $\begin{array}{r}100- \\
150\end{array}$ & & \multicolumn{2}{|c|}{ Wens verwerkende partijen } & \\
\hline Grasklaver & Droge stof $(\%)$ & & & & & & & & & & & & \\
\hline Kool & $\begin{array}{l}\text { Bladaantasting } \\
(\%)\end{array}$ & & & & & & & & & & & & \\
\hline Lelie & \begin{tabular}{|l|}
$\begin{array}{l}\text { Aantal bollen } \\
(\mathrm{n} / \mathrm{ha})\end{array}$ \\
\end{tabular} & & & & & & & & & & & & \\
\hline Peen & Tarra (\%) & & 0 & & & 5,6 & & & 26,9 & & & $\begin{array}{l}\text { Meuffels \& Kroonen } \\
(2017)\end{array}$ & $\begin{array}{l}\text { Eigen data praktijkperceel } \\
\text { BKZ (2019) }\end{array}$ \\
\hline Pootaardappel & Schurft (\%) & 0 & & & 3 & & & 5 & & & & \multicolumn{2}{|c|}{ Schatting o.b.v. Bus (2002) } \\
\hline Prei & Tarra (\%) & 0 & 0 & 0 & & 12 & & & 17 & & & \multicolumn{2}{|c|}{ Schatting o.b.v. de Kraker (n.d.) } \\
\hline Snijmais & VEM & & 1050 & & & 990 & & & 984 & & & \multicolumn{2}{|l|}{ Eurofins (2019) } \\
\hline Suikerbiet & Suikergehalte $(\%)$ & 18 & 18 & 18 & 17 & 17 & 17 & 16,34 & 16,34 & 16,34 & Quiesen (2019) & Quiesen (2019) & Quiesen (2019) \\
\hline \multicolumn{14}{|l|}{ Tagetes } \\
\hline $\mathrm{Ui}$ & Tarra (\%) & 0 & 0 & 0 & 1,5 & 1,5 & & 10 & 10 & & & & \\
\hline $\begin{array}{l}\text { Zetmeelaardapp } \\
\text { el }\end{array}$ & $\begin{array}{l}\begin{array}{l}\text { Zetmeelgehalte } \\
(\%)\end{array} \\
\end{array}$ & & & 27,8 & & & 21,5 & & & 19,4 & \multicolumn{3}{|l|}{ Avebe (2020) } \\
\hline Zomergerst & $\begin{array}{l}\text { Eiwitgehalte (\%) } \\
\text { DKG } \\
\end{array}$ & & & & & $45-50$ & $9,5-11,5$ & & & & \multicolumn{3}{|c|}{$\begin{array}{l}\text { Wens verwerkende partijen } \\
\text { Handboek Zomergerst }\end{array}$} \\
\hline Zomertarwe & Vochtgehalte (\%) & & & & & & & & & & & & \\
\hline
\end{tabular}




\section{Bijlage 5 Streefwaarden fosfaatoverschot}

De doelgerichte streefwaarde is gebaseerd op Tonnijck \& de Haan (2006), en is afhankelijk van de fosfaattoestand (zie Tabel 5-4).

Tabel 5-4 Doelgerichte streefwaarden voor het fosfaatoverschot

\begin{tabular}{|r|r|r|}
\hline Fosfaatstatus (Pw-getal) & Gewenst fosfaatoverschot (kg P2O5 ha-1) \\
\hline & $<20$ & 140 \\
\hline $20-30$ & $>30$ & 10 \\
\hline
\end{tabular}

De streefwaarde voor de goede landbouwpraktijk is gebaseerd op het Handboek Bodem en Bemesting. Daarin wordt gesteld dat indien een fosfaatstatus gelijk of hoger is dan de streefwaarde, maar lager dan Pw 45 gehandhaafd dient te worden. Daarvoor moet de afvoer gecompenseerd worden, plus het onvermijdbare verlies. Deze wordt op $5 \mathrm{~kg}$ P2O5 ha-1 gesteld, met als bijbehorende opmerking dat de precieze omvang van de onvermijdbare verliezen niet met zekerheid vastgesteld is. Indien de fosfaattoestand lager is dan de streefwaarde, dient een extra hoeveelheid fosfaat aangevoerd te worden om het Pw-getal te verhogen tot 25 op zeeklei en zeezand en 30 op overige gronden (zie Tabel 5-5).

Tabel 5-5 Hoeveelheid fosfaat ( $\mathrm{kg} \mathrm{P2O5} \mathrm{ha-1)} \mathrm{die} \mathrm{boven} \mathrm{de} \mathrm{onttrekking} \mathrm{nodig} \mathrm{is} \mathrm{om} \mathrm{het} \mathrm{Pw-getal} \mathrm{te}$ verhogen tot 25 op zeeklei en zeezand en 30 op de overige gronden (uit het Handboek Bodem en Bemesting).

\begin{tabular}{|r|r|r|r|}
\hline Fosfaatstatus (Pw-getal) & Zeeklei en zeezand & Dekzand, dalgrond, rivierklei en löss \\
\hline 1 & 1500 & 1710 \\
\hline 5 & 1130 & 1340 \\
\hline 10 & 780 & 990 \\
\hline 15 & 490 & 700 \\
\hline 20 & 230 & 440 \\
\hline 25 & 0 & 210 \\
\hline
\end{tabular}

De regionale referentiewaarde is respectievelijk 13 en $10 \mathrm{~kg} \mathrm{P2O5}$ ha $^{-1}$ voor klei en dal- en overige zandgronden. 


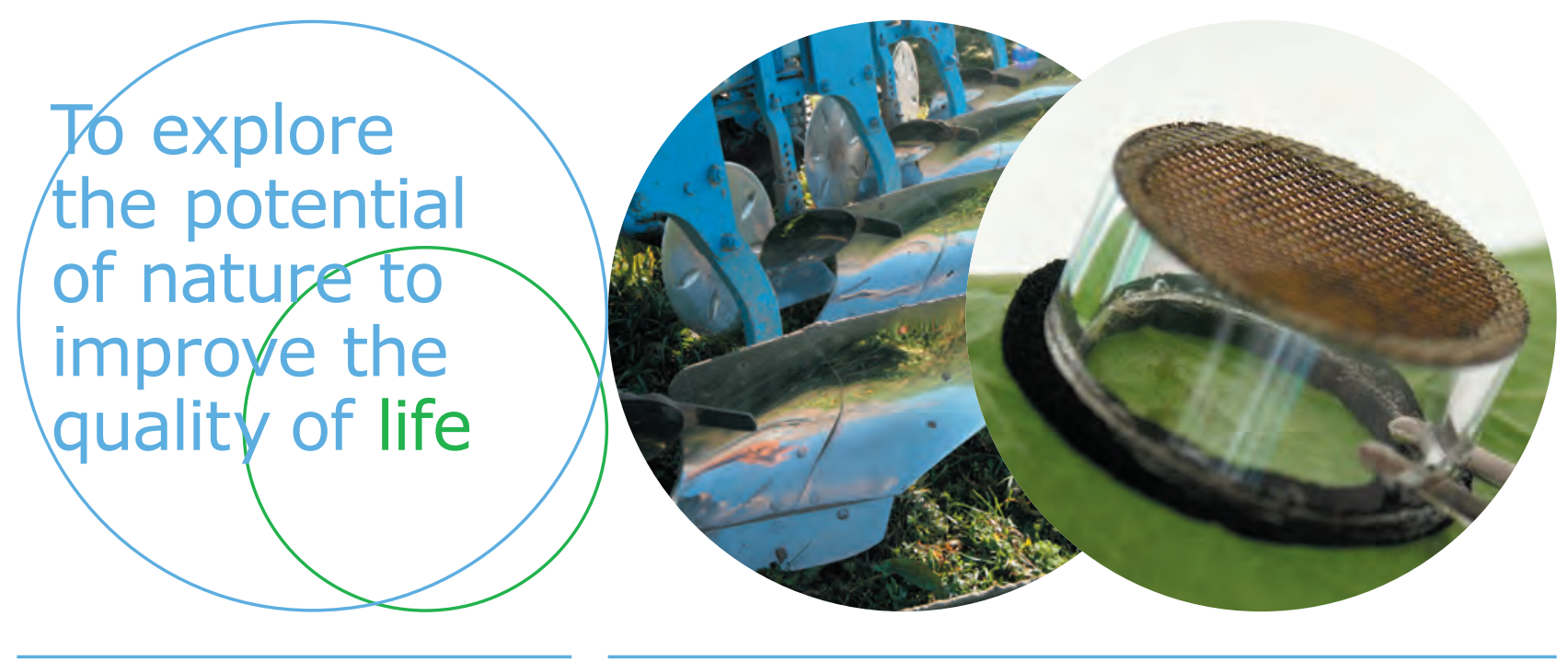

Wageningen University \& Research

\section{Open Teelten}

Edelhertweg 1

Postbus 430

8200 AK Lelystad

$\mathrm{T}(+31) 320291111$

www.wur.nl/openteelten

Rapport WPR-899
De missie van Wageningen University \& Research is 'To explore the potential of nature to improve the quality of life'. Binnen Wageningen University \& Research bundelen 9 gespecialiseerde onderzoeksinstituten van stichting DLO en Wageningen University hun krachten om bij te dragen aan de oplossing van belangrijke vragen in het domein van gezonde voeding en leefomgeving. Met ongeveer 30 vestigingen, 6.500 medewerkers en 12.500 studenten behoort Wageningen University \& Research wereldwijd tot de aansprekende kennisinstellingen binnen haar domein. De integrale benadering van de vraagstukken en de samenwerking tussen verschillende disciplines vormen het hart van de unieke Wageningen aanpak. 